\title{
A comparative analysis of the precipitation extremes obtained from TRMM satellite and rain gauges datasets over a semi-arid region
}

\author{
by Mahbod, M., Shirvani, A. and Veronesi F.
}

Copyright, Publisher and Additional Information: This is the author accepted manuscript. The final published version (version of record) is available online via Wiley. This article may be used for non-commercial purposes in accordance with Wiley Terms and Conditions for Self-Archiving.

Please refer to any applicable terms of use of the publisher.

DOI: https://doi.org/10.1002/joc.5824

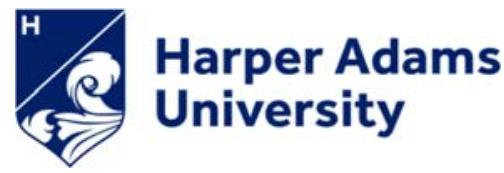

Mahbod, M., Shirvani, A. and Veronesi F. 2018. A comparative analysis of the precipitation extremes obtained from TRMM satellite and rain gauges datasets over a semi-arid region. International Journal of Climatology. 
1 Full title: A comparative analysis of the precipitation extremes obtained

2 from TRMM satellite and rain gauges datasets over a semi-arid region

3 Short title (running head): Precipitation extremes by TRMM \& rain gauges

4 Mehdi Mahbod $^{1}$, Amin Shirvani ${ }^{2}$, Fabio Veronesi ${ }^{3}$

5 1. Department of Water Sciences \& Engineering, College of Agriculture, Jahrom University, Jahrom, I.R. Iran. Postal Code: 74137-66171. Email: mehdi.mahbod@jahrom.ac.ir; mahbod001@yahoo.com.

2. Department of Water Engineering, Oceanic and Atmospheric Research Center, College of Agriculture, Shiraz University, Shiraz Postal Code: 71441-33111, Iran. E-mail: am_shirvani@hotmail.com; ashirvani@shirazu.ac.ir.

3. Crop and Environment Sciences Department, Harper Adams University. Newport, Shropshire, TF10 8NB - United Kingdom

Corresponding author: Mehdi Mahbod 


\section{A comparative analysis of the precipitation extremes obtained from}

\section{TRMM satellite and rain gauges datasets over a semi-arid region}

18 Abstract

19 The objectives of this research were to compare precipitation extremes obtained from TRMM

20 satellite and those of rain gauges over a semi-arid area in Iran. Extreme precipitation indices

21 (EPIs) (i.e. the number of days with precipitation value over $10 \mathrm{~mm}$, maximum duration of

22 wet and dry days, the number of days with precipitation over the $95^{\text {th }}$ percentile, total

23 precipitation higher than the $95^{\text {th }}$ percentile, and maximum daily precipitation) were

24 calculated across Fars province, Iran, 2000-2014 at seasonal time scales. The gauges data

25 were interpolated at the spatial resolution of $0.25^{\circ} \times 0.25^{\circ}$ to match the $3 \mathrm{~B} 42$ data using

26 Inverse Distance Weighting (IDW). Then EPIs from the two datasets were compared with

27 each other. The findings showed that mean values computed from gauges and satellite data

28 did not present any significant differences among all of the extreme indices. Furthermore,

29 their variances presented a good level of congruence. Finally, the majority of indices

30 presented a satisfactory correlation between the two dataset. To evaluate the prediction of

31 extreme events in different temporal and tolerated distances, a fuzzy method was used. The

32 results showed that the percentage of grid cells with useful predictions tripled with extending

33 spatial tolerance by just one pixel. To evaluate methods of eliminating the uncertainty of

34 probable missing rainfall data and the seasonal changes in rainfall averages, probabilistic

35 methods based on Weibull distribution and truncated geometric distribution were employed

36 to eliminate uncertainties in estimation of extreme precipitation amounts and extreme wet 
37 periods. The results showed that as to extreme precipitation amounts, a satisfactory method

38 could not be drawn for arid southern regions of Fars, Iran .Similarly, as to extreme wet

39 periods, the consistency between gauges and satellite data could not be improved

40 significantly.

41 Keywords: Extreme precipitation, TRMM satellite, Rain gauges, Fars province.

\section{1. Introduction}

43 Precipitation is an important meteorological parameter in the climatic, agricultural, and

44 hydrological studies of a region. Traditionally, precipitation is measured in rain gauges with

45 a good accuracy. However, precipitation is a parameter with high spatial variations. Most

46 rain gauges are located in regions of easy reach by human operators - they have a very low

47 density in regions far from cities or on very high mountains (Nastos et al., 2016). This creates

48 a clear issue of coverage, which can be partially solved with remote sensing technologies

49 (e.g. radar systems and earth-observing satellites), which are used to continuously estimate

50 precipitation at global scales.

51 In the past two decades, some satellites-based programs including Global Precipitation

52 Climatology Project (GPCP) (Huffman et al., 2001), the Climate Prediction Centre Morphing

53 technique (CMORPH; Joyce et al., 2004), Tropical Rainfall Measuring Mission (TRMM),

54 Multi-sensor Precipitation Analysis (TMPA) (Huffman et al. 2007), Precipitation Estimation

55 from Remotely Sensed Information using Artificial Neural Network (PERSIANN; Hsu et al.,

56 1997), PERSIANN Cloud Classification System (PERSIANN-CCS; Hong et al., 2007),

57 PERSIAN-CDR (Ashouri et al., 2015) and Global Satellite Mapping of Precipitation 
58 (GSMaP; Ushio et al., 2009) have been developed to estimate precipitation. Moazami et al. 59 (2016) evaluated the daily precipitation data of four widely-used satellite rainfall estimates 60 (TMPA-3B42V7, TMPA-3B42RT, PERSIANN, and CMORPH) on a dense rain gauge 61 network over six regions in Iran with various physiographic and climatic conditions. They 62 concluded that the most accurate estimation of the daily precipitation was obtained from 63 TMPA-3B42V7. Other studies for evaluation of the data estimated by the TRMM satellite 64 across different parts of the world include studies over Iran (Javanmard et al., 2010; Alijanian 65 et al. 2017), Greece (Nastos et al., 2016), India (Prakash et al., 2016b, 2018), Bangladesh 66 (Tarek et al., 2017), Ethiopia (Awange et al., 2016), China (Zhao and Yatagai., 2014; Cai et 67 al., 2016; Zhao et al., 2017), and the United States of America (Prat and Nelson, 2014; Chen 68 et al., 2013; Qiao et al.,2014). In all of these studies, acceptable results were obtained from the TRMM data. The TRMM ended its mission in 2015 and was replaced with Global 70 Precipitation Measurement (GPM) (Prakash et al., 2016a; Skofronick-Jackson et al., 2017; 71 Manz et al. 2017).

73 To examine the precipitation phenomenon in a region, the calculation and evaluation of the 74 extreme precipitation values are crucial for management and decision-making under extreme 75 environmental conditions, including flood and drought. Various studies have been conducted 76 regarding extreme precipitation, including studies by Hajani and Rahman (Australia, 2018), 77 Shrestha et al. (Koshi basin river, 2017), Najafi and Moazami (2016), Wang et al. (China 78 and USA, 2014), Raveh-Rubin and Werneli (Mediterranean region, 2015) and Tangang et al. 79 (Indonesia, 2017). However, only a few studies have been conducted for the comparison of 
82 less than satisfactory. Katiraie-Boroujerdy et al. (2017) used PERSIAN-CDR data to

extreme precipitation values obtained from satellite data and rain gauges. Lockhoff et al. (2014) evaluated European precipitation extremes obtained by GCPC and found them to be evaluate the extreme precipitation indices (EPIs) over a subtropical semi-arid region. They concluded that PERSIANN-CDR mostly underestimated the indices. Pombo and Oliveira (2015) calculated the maximum annual daily precipitation in Angola based on ground rain gauges and TRMM satellite. They indicated that TRMM underestimated maximum annual daily precipitation. Nastos et al. (2013) compared ETCCDI extreme indices of the Mediterranean Sea obtained from ground rain gauges and TRMM satellite data and reported a significant difference between the two datasets. Bharti et al. (2016) used the TRMM 3B42 version 7 (3B42) precipitation data to investigate extreme rainfall events during the monsoon season over the Northwest Himalaya for the period 1998-2013. However, their study did not include a comparison between satellite and ground data. Considering the limited number of studies regarding the evaluation of extreme precipitation values of TRMM satellite especially in Iran, the researchers have compared the estimated precipitation extremes from 3B42 and rain gauges in a semi-arid region of Iran.

\section{Material and methods}

\subsection{Study area and data used}

The relative dry climate coupled with the indiscriminate withdrawal of groundwater has intensified pressure on water resources and exacerbated the water crisis in Iran. This calls for an enhanced management of water resources, which must start with a better management of 
101

102

103

104

105

106

107

108

109

110

111

112

113

114

115

116

117

118

119

120

121 122 rainy days (INT), CV decreased by 50\%. Precipitation over the Middle East and Iran is

meteoritic water. Fars province is one of the centres of livestock and arable farming in Iran, which is located between the latitudes $27^{\circ} 3^{\prime}$ and $31^{\circ} 42^{\prime}$ and the longitudes $50^{\circ} 30^{\prime}$ and $55^{\circ} 36^{\prime}$ (Figure 1a), partly covered by the Zagros mountain chain northwardly. It is also close to the Persian Gulf southwardly and Khuzestan Plain borders westwardly (Azadi and KarimiJashni, 2016). According to the digital elevation model (DEM) maps generated by Shuttle Radar Topography Mission (SRTM) a wide range of altitudes is observed in Fars with a minimum elevation of just $114 \mathrm{~m}$, and a maximum of $3922 \mathrm{~m}$ above sea level (Figure 1b). The unique geographic location of Fars along with the high variation of altitudes result in different climatic zones, namely, temperate semi-arid, temperate desert arid, cold semi-arid, temperate Mediterranean, cold desert arid, warm desert arid, and warm semi-arid based on modified De-Marton's classification method (Soufi, 2004).

Figure 2 (a) indicates average of annual precipitation (RTOT, mm), mean number of wet days in a year (NWET, day), average of annual precipitation over all wet days (INT, mm day $\left.{ }^{1}\right)$, and the $95^{\text {th }}$ percentile from the empirical (wet day) distribution functions $(\mathrm{Q} 95, \mathrm{~mm})$, obtained from the rain gauges of Far province, 2000-2014. RTOT ranges from $125 \mathrm{~mm}$ in the southern and eastern regions of the province to near $1000 \mathrm{~mm}$ in the northwestern parts. Zagros Mountain chain plays a significant role in the precipitation diversity of Fars. Although a similar spatial trend is obvious for NWD, RTOT, INT, and Q95, the spatial variation coefficient $(\mathrm{CV})$ for these parameters were not the same across the rain gauges, so that $\mathrm{CV}$ for Q95, INT, NWD, and RTOT were 0.21, 0.24, 0.27 and 0.47, respectively. Therefore, the highest CV was related to RTOT, and when the rainfall was normalized with the number of 
123 usually related to moist air masses originated in the Mediterranean Sea and the southern water

124 bodies (Arabian sea, Oman Sea, Persian Gulf, Red Sea, and north Indian ocean; Raziei et al.

125 2012). To identify rainy months, the climatological means of monthly precipitation over

126 Fars province is presented in Figure 3 for the period $2000-2014$, which shows the rainy

127 months are from November to April, with only 3 percent of annual precipitation occurring

128 from May to the end of October and with the highest monthly precipitation occurring in

129 December and January.

130 In order to maintain the quality of rain gauges data, of the total number of stations available

131 ( $\mathrm{n}=137), 90$ stations were selected, with continuous data between January ${ }^{1 \text { st }} 2000$ to

132 December29 ${ }^{\text {th }}$ 2014. The dataset was obtained from Fars Regional Water Organization. The

133 coordinates and statistical characterizations (mean, minimum and maximum, and standard

134 deviation) of the gauges under investigation for the annual time scale are provided in Table

135 S1 as Supporting Information. According to Zolina et al. (2005, 2010), heavy precipitation

136 and dry and wet periods are practically insensitive to gaps in daily time series lower than

137 10\%. However, according to Fars Regional Water Organization, there are less than 5\%

138 missing values in the reported precipitation data. Hence, to increase certainty, the researchers

139 used Double Mass Curve method (DMC; McCuen, 2016) to check the relative homogeneity

140 of the precipitation data. Therefore, the researchers plotted accumulated rainfall at each

141 station against the average accumulation for two adjacent stations with a high correlation.

142 The $\mathrm{r}^{2}$ values accounted for over $99 \%$ of the statistical variance. In other words, only less

143 than one percent of the statistical variance remained unexplained. When plotted curves for

144 DMC were checked, missing values were only found in station No. 29. To remedy the 
145 problem, the researchers adjusted the precipitation values in the suspicious days for this

146 station as proposed by Ouma et al. (2012).

147 The TRMM satellite was launched on 9 November 1997 and it ended collecting data on April

14815,2015 . The $3 \mathrm{~B} 42$ product covers the latitude range $50^{\circ} \mathrm{S}-50^{\circ} \mathrm{N}$ with the basic temporal 149 resolution of 3 hours. The daily precipitation data of TRMM 3B42 Version 7 (3B42) has

150 been downloaded from the Goddard Earth Sciences Data and Information Services Centre

151 (GES-DISC, http://mirador.gsfc.nasa.gov) with spatial resolution of $0.25 \times 0.25$ and

152 temporal resolution of one day for the period of 1 January 2000 to 29 December 2014. The

153 geographic location of 3B42 grid cells, which are located in the area of rain gauges data

154 interpolation, are depicted in Figure 4. The researchers also compared the daily rainfall data

155 between the rain gauges and the nearest 3B42 grid cells and obtained the following results:

156 correlation coefficient $=0.67$, root mean square error $=8.5 \mathrm{~mm}$, prediction of detection $=0.58$,

157 false alarm ratio $=0.51$, and critical success index $=0.36$ (all measures are described in

158 Moazami et al. (2016)).

$159 \quad 2.2$ Interpolation

160 As the location of the rain gauges does not match the gridded 3B42 data, it is first necessary

161 to interpolate the rain gauge data at $0.25^{\circ} \times 0.25^{\circ}$ for each day. Four methods are commonly

162 used to interpolate precipitation values as follows: kriging, inverse distance weighted (IDW)

163 and thin plate spline (TPS) (Webster and Oliver, 2007), as well as a method suggested by

164 Haylock et al. (2008). The latter involves a three step approach where monthly means are

165 interpolated using TPS, then daily local precipitation are normalized (by dividing them for 
166 the monthly mean for the same location) and the interpolation of anomalies using kriging.

167 Therefore, the researchers applied a five-fold cross-validation (James et al. 2013) framework

168 to determine which method performed the best for this particular dataset. Results (Table 1)

169 are computed using the mean absolute error as an index that measures the average difference

170 between observed and estimated rainfall values. These indicate that IDW and Haylock's

171 method are the most accurate method for the large majority of years. Moreover, their average

172 accuracy over the entire time period is essentially the same. The researchers finally decided

173 to use IDW, since it is the simplest method to apply; it provides accurate results; and it is

174 easy to automate in ArcGIS.

175 Technically, raster layers for 5,499 days (from 1 January 2000 to 29 December 2014) were

176 prepared, based on the daily data of the rain gauges for Fars province. The necessity to

177 perform such a large number of daily interpolations caused us to automate the task using

178 inverse distance weighted (Pombo and Oliviera, 2015) interpolation in Python within the

179 ArcGIS 10.3 framework. The objective of any interpolation method is to estimate the value

180 of a parameter at unmeasured locations based on a discrete set of observations, i.e. rain

181 gauges. However, in locations far from gauges there may be a discrepancy between estimated

182 data and real rainfall amount, which creates a certain amount of uncertainty in the

183 interpolated values. Inverse distance is not capable of assessing this level of uncertainty.

184 Other algorithms, e.g. kriging, are capable of interpolating univariate data and provide local

185 uncertainty. Nonetheless, in this study the number of gauges is not sufficient for this method

186 to be applied successfully (Webster and Oliver, 2007). Additionally, the assumption that rain

187 gauges provide a realistic measurement of precipitation events has also been questioned in 
188

189

190

191

192 indices have been proposed by the Expert Team on Climate Change Detection and Indices

193 (ETCCDI) (Zhang et al. 2011) as indicated in Table 2. The indices R10mm and R20mm

194 show the number of days with precipitation higher than 10 and $20 \mathrm{~mm}$, respectively. As

195 shown in Figure 2, mean intensity for all rain gauges except for one was lower than $20 \mathrm{~mm}$.

196 As a result, the researchers considered only R10mm in this paper. The two indices CWD and

197 CDD indicate the maximum number of wet or dry durations in a period of time. The

198

199

200

201

202

203

204

205

206

207

208

209 precipitation intensity (INT) is equivalent to SDII (Table 2), which is investigated in section 4.1 (climatological statistics). The percentile indices could be obtained by comparing the value of daily precipitation with a threshold value. If it is higher than the threshold on a certain day, that is considered to be a day with extreme rainfall. The threshold value is obtained from the 95 or $99^{\text {th }}$ percentile of long term series of precipitation in a location. Since climate in area under investigation is semi-arid, the $99^{\text {th }}$ percentiles were excluded. Likewise, since the occurrence of five consecutive rainy days was nonexistent in most grid cells even in rainy seasons, the researchers did not consider Rx5day, either.

Although some researchers have used ETCCDI indices to study extreme precipitation (e.g. Heidinger et al. 2018, Li et al. 2018), others have raised objections to these indices due to uncertainties for the estimation of maximum consecutive wet/dry days (CWD/CDD) and the sensitivity of these indices to lost data. Likewise, similar objections have been raised to 
210 percentile indices such as R95pTOT (Zolina et al. 2009, Zolina et al. 2013, Leander et al.

211 2014). For percentile indices, changes in total rainfall or the number of wet days have been

212 reported as sources of uncertainty in the trend analysis. Thus, alternative methods have been 213 presented to eliminate uncertainty (Zolina et al. 2009, Leander et al. 2014). The employed

214 methods for percentile indices and wet/dry spells (CWD/CDD) are explained in sections

$215 \quad 2.3 .1$ and 2.3.2, respectively.

\section{$216 \quad 2.3 .1$. Percentile extremes}

217 There are two absolute and relative general approaches to calculate the percentile indices. In 218 the absolute approach, the amount of rainfall events that exceeds the percentile of long-term 219 rainfall time series would be considered as extreme precipitation value (similar to the 220 definition of ETCCDI, Table 2). However, in the relative approach, the amount of rainfall in 221 extreme events is divided by the total rainfall of a single year or season. This approach was 222 adopted by Klein Tank and Können (2003) for the first time. The main feature of this 223 approach is that it considers the effect of a change in the total rainfall on changes in the 224 amount of extreme events. However, in some areas or seasons with few wet days, this method 225 will produce some uncertainty (Zolina et al., 2009). The increase in heavy precipitation could 226 well be a function of variations in total precipitation or it could be due to increased 227 precipitation and decreased number of wet days (e.g. Zolina et al. 2004, 2008). To counteract 228 this uncertainty, Zolina et al (2009) provided Distribution of Fractional Contribution (DFC) 229 based on gamma distribution for daily rainfall to calculate relative percentile indices in a 230 season. They mentioned that this proposed percentile extreme index is more stable, especially 231 when precipitation extremes are estimated from a limited number of wet days of the seasonal 232 or monthly time series. Leander et al. (2014) addressed another uncertainty of proposed index 
233 by Zolina et al. (2009) - the fact that a change in the mean also affects the estimated percentile

234 extreme even when the shape of the distribution is unchanged. Therefore, a trend within the 235 percentile extreme index doesn't essentially represent a modification within the distributional 236 form related to an amplified response of maximum precipitation.

237 In this study, the researchers evaluated the estimations of relative percentile precipitation 238 extremes of 3B42 data by employing the method proposed by Leander et al. (2014). 239 According to Klein Tank and Können (2003) definition, R95pTOT could be approximated 240 as follows (Leander et al. 2014):

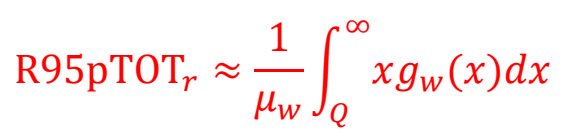

241 where $Q$ is long term $95^{\text {th }}$ percentile, $\mu_{w}$ and $g_{w}$ are the average and the probability density

242 function of wet days precipitation. Leander et al. (2014) proposed to use $95^{\text {th }}$ percentile in a

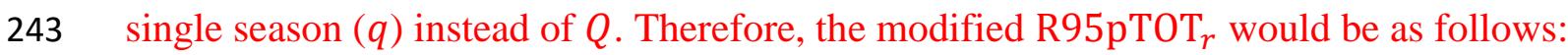

$$
\text { RS95pTOT } \approx \frac{1}{\mu_{w}} \int_{q}^{\infty} x g_{w}(x) d x=\int_{\frac{q}{\mu_{w}}}^{\infty} x^{\prime} g_{w}{ }^{\prime}\left(x^{\prime}\right) d x^{\prime}
$$

244 where $x^{\prime}$ is $\frac{x}{\mu_{w}}$ and $g_{w}{ }^{\prime}$ is the density function of $x^{\prime}$. Leander et al. (2014) proposed two245 parameter Weibull distribution for $g_{w}$. Therefore, the probability density of shifted (as $\delta$ )

246 Weibull distribution is given as follows:

$$
g_{w}(x)=\frac{c}{a}\left(\frac{x-\delta}{a}\right)^{c-1} \exp \left[-\left(\frac{x-\delta}{a}\right)^{c}\right], x \geq \delta
$$

247 where $a$ and $c$ are scale and shape parameters, and $\delta$ is the wet-day threshold precipitation 248 (i.e. $1 \mathrm{~mm}$ ). The final expression for RS95pTOT would be as Equation (4). 


$$
\text { RS95pTOT } \approx \frac{a \Gamma\left(1+\frac{1}{c}\right)}{\delta+a \Gamma\left(1+\frac{1}{c}\right)}\left[\frac{0.05 \delta}{a \Gamma\left(1+\frac{1}{c}\right)}+1-P\left(\frac{1}{c}+1,-\log (0.05)\right)\right]
$$

249

250 where $\Gamma$ is gamma function and $P$ is the normalized incomplete gamma function. For

251 estimation of $c$, two-parameter Weibull distribution was fitted to the wet-days amounts (over

$252 \delta$ ) using maximum likelihood method (Wilks, 2011).

253 In addition, results were obtained on an individual basis per season to account for the ever-

254 changing precipitation patterns and weather regimes, which affected the accuracy of the 255 satellite-based estimates as well as the uncertainty of the in situ measurements. The seasons 256 were outlined as winter: December to February (DJF), spring: March to May (MAM), 257 summer: June to August (JJA), and autumn: September to November (SON). According to 258 Leander et al. (2014) seasons with 10 or more wet days were considered for 259 calculating $R S 95 p T O T$. Due to low rate of precipitation in summer, this season was excluded 260 from this study. Since the highest amount and frequency of rainfall occur in winters and the 261 limit to provide all of results, the researchers presented them for winters in details, while for 262 the other seasons (spring and autumn) the overall results were reported

\section{$263 \quad$ 2.3.2. Wet/dry spells}

264 To distinguish between dry and wet days, $1 \mathrm{~mm}$ precipitation was taken as the threshold value 265 as proposed by Groisman and Knight (2008). Furthermore, wet periods (WPs) and dry 266 periods (DPs) were considered separately for the wet season (October-March) and dry season 267 (April-September). Traditional seasonal schedules would lead to noticeable uncertainties 268 when estimating the durations of WPs and DPs because wet and dry periods are not 
necessarily confined within seasonal boundaries. (Zolina et al., 2013). Consequently, the researchers attributed WPs to the season in which they began. However DPs were attributed

271 to the season that included longer durations of the dry periods. This was considered necessary 272 because of long dry periods in the dry season. Maximum values of WPs and DPs (CWD and 273 CDD, respectively) were considered by ETCCDI as an extreme precipitation parameter in a 274 season or year (Table 2).

275 The analysis of wet and dry periods is highly sensitive to the continuity of records. In order 276 to remove this limitation from the current study, as suggested by Zolina et al. (2013), the 277 researchers fitted Truncated Geometric Distribution (TGD) to the data. The probability 278 density function (PDF) of the TGD is given as follows (Zolina et al., 2013):

$$
P\left(x_{i}=k\right)=\frac{1}{1-(1-p)^{N}} p(1-p)^{k-1}
$$

279 where $x_{i}$ is the duration of the continuous wet (dry) period in days, $p$ is the distribution 280 parameter, which is the inverse of mean duration (wet/dry) in the standard geometric 281 distribution, and $\mathrm{N}$ is the maximum of WPs/DPs. The PDF derivation of TGD is explained

282 in details by Zolina et al. (2013). By using Equation (5), percentiles related to a given wet/dry 283 duration could be estimated and vice versa. To examine the goodness of fitness of the TGD 284 on the data, Chi-square test was applied, which showed that there was not any significant 285 differences between the distribution of WPs/DPs and TGD at the grid cells at 5\% 286 significance level.

\subsection{Data analysis}


The Pearson correlation coefficient (r) was used to assess the correlation between $3 \mathrm{~B} 42$ and $\mathrm{RG}$ results. The bias ratio (BR; the ratio of $3 \mathrm{~B} 42$ results and $\mathrm{RG}$ ) was used to quantitatively compare the results of the two datasets. The two-sample t-test (Snedecor and Cochran, 1989) and the Mann-Whitney U test (MW; Stedinger et al., 1993) were used to check the 292 homogeneity of the means. Moreover, the Levene test- based on the median- and F test were used to check the homogeneity of the standard deviations of the two datasets (Nordstokke et 294 al., 2011). All statistical tests were performed at 5\% significance level.

295

296

297

298 299 300 301 302 303 304

$$
F S S=1-\frac{\sum_{N}\left(\left\langle P_{3 B 42}\right\rangle_{S}-\left\langle P_{R G}\right\rangle_{S}\right)^{2}}{\sum_{N}\left\langle P_{3 B 42}\right\rangle_{S}^{2}+\sum_{N}\left\langle P_{3 B 42}\right\rangle_{S}^{2}}
$$

305 where $\left\langle P_{3 B 42}\right\rangle$ and $\left\langle P_{R G}\right\rangle$ are the fraction of grid boxes in a neighborhood with extreme events 306 observed by 3B42 and RG, respectively, $\mathrm{N}$ is the number of neighborhood in the domain 307 considered, and \langle\rangle$_{S}$ indicate that the fractions are calculated based on the neighborhood 
308

309

310

311

312

$$
F S S_{\text {usefull }}=0.5+\frac{f_{y}}{2}
$$

313 where $f_{y}$ is the domain average fraction observed by the reference dataset (Roberts and Lean

314 2008); that is, here the average fraction of extreme events observed by RG at a specific grid

315 point over the entire time period.

316 Extreme thresholds were calculated per grid box at a $0.25^{\circ}$ resolution. The extreme

317 thresholds were averaged over the increased spatial neighborhood. As the size of the 318 neighborhood increased, the neighborhood window crossed the borders of the study area; 319 therefore, it included no-data values. Thus, a neighborhood was scrutinized only when at 320 least $50 \%$ of the neighborhood grid boxes provided valid values. This led to a decrease in the 321 size of the area along the borders with increasing spatial scale.

322

323 4. Results

\section{4.1. Climatological statistics}

325 Before investigating the extreme indices, based upon 15 years (2000-2014) of daily rainfall 326 estimates, total rainfall (TOT), number of wet days (NWD), and wet day intensity (INT) were 327 calculated for 3B42 and RG at seasonal time scales and different years. Qualitatively, Figure 
3285 shows that the spatial patterns compared TOT with NWD satisfactorily. The north and 329 northwest regions of the province had the highest values, while the southern and southeast 330 grid cells of the province had the lowest values. However, the spatial distribution of INT in 331 the southeastern regions based on 3B42 did not correspond to the results of RG, suggesting 332 that it might be due to underestimation of NWD in these regions. According to BR maps, 333 3B42 underestimated NWD (88\% of the grid cells). Pierre et al. (2011) also reported 334 underestimation of NWD by 3B42 in Sahelian belt, Africa. Correlation (r) between 3B42 and 335 RG results decreased for TOT, INT and NWD, respectively. Buarque et al. (2011) also 336 reported a higher correlation for estimation of TOT than NWD by 3 B42 in the Amazon region.

337 As shown in Table 3, the mean test results indicated that the NWD had the highest number 338 of grid cells with different means at probability level of 5\%. However, the magnitude of 339 results was not the same at different time scales, so that it was the highest for winter season.

340 This might be due to higher number of precipitation events in this season. Furthermore, the 341 most insignificant percentage of means was obtained for TOT. On the other hand, Levene 342 and $\mathrm{F}$ tests showed that the highest percentage of grid cells with different variances were 343 related to INT except for the Levene test in autumn, which identified NWD with the highest 344 percentage of significant difference.

345 4.2. R10mm and Rx1Day

346 The means of R10mm and Rx1Day obtained by 3B42 and RG datasets across Fars province 347 for the period 2000-2014 along with the corresponding spatial distributions of BR and $\mathrm{r}$ are 348 indicated in Figure 6. The means of the aforementioned indices calculated from RG and $3 \mathrm{~B} 42$ 349 datasets were almost identical for spatial variation, and so were they with respect to the 
minimum of estimated R10mm; nonetheless, the same indices calculated from 3B42 dataset

351 indicated more grid cells with the minimum range (2.1 - 4 days) in south and eastern parts

352 of the study area. With respect to BR map, 3B42 underestimated R10mm in over $81 \%$ of the 353 grid cells. The rate of underestimation decreased in other seasons. As shown in Table 1, the 354 average BR across the studied region was 1.02 for spring and autumn. Contrary to R10mm, 355 overestimation was predominant in the Rx1day, so that the BR mean for spring and autumn 356 winter seasons were 1.16, 1.08 and 1.3, respectively (Table 4.). Regarding the correlation 357 coefficient (Figure 6), in $63 \%$ and $81 \%$ of grid cells for R10mm and in $38 \%$ and $65 \%$ of grid 358 cells for Rx1Day, the correlation coefficient was greater than 0.7 and 0.6 , respectively. This 359 shows a better accordance for the estimated values of R10mm than Rx1Day. Similar results 360 were obtained for spring and autumn. As shown in Table 4, the spatially averaged values of $361 \mathrm{r}$ for R10mm were higher than those for Rx1Day.

362 Table 4 depicts MW and test results. The maximum difference between the means of 363 Rx1Day and R10mm indices calculated from 3B42 and RG was observed in the winter (i.e., $36412 \%$ of the grid cells). In other seasons (spring and autumn), a better match was found 365 between the results. Thus, overall, the consistency between the means of the aforementioned 366 indices was very good. As to the equal variance tests, except for $\mathrm{F}$ test in winter, which 367 indicated a significant difference for Rx1Day in $28 \%$ of grid cells, the results of other 368 parametric and non-parametric equal variance tests were satisfactory in all seasons for both 369 of the EPIs.

\section{$370 \quad$ 4.2. Percentile indices}


371 As shown in Figures 7 and 8, the R95pTOT and total number of days with precipitation

372 higher than Q95 (R95pDay) values were computed to compare the amount and frequency of

373 determined extreme events by $3 \mathrm{~B} 42$ and RG datasets. Then, fuzzy analysis was employed to 374 compare the ability of this index to predict the occurrence of precipitation amounts higher 375 than Q95 in different temporal and spatial neighbors (Figure 9). Finally, the improved index 376 RS95pTOT was indicated in Figure 10.

377 As shown in Figure 7, the spatial distribution of R95pTOT obtained by 3B42 and RG 378 overlapped in the margins of Fars province. However, 3B42 results depicted a zone with high 379 values of extremes in central parts of the province. A similar difference in spatial pattern of 380 3B42 and RG results was also observed in Figure 8 for the R95pDay. According to the BR 381 maps (Figures 7 and 8), it is obvious that 3B42 overestimated R95pTOT (R95pDay) in $38270(63) \%$ of grid cells, as the spatial average value of BR was 1.3 (1.17).

383 Average values of $r$ for R95pTOT (0.76) and R95pDay (0.71) confirm that good correlations 384 existed between the results of RG and 3B42 in winter; however, the $r$ values were lower in 385 south-eastern parts of Fars, where lower amount and frequency of precipitation exists. With 386 a similar spatial pattern (results are not shown), the average $r$ for R95pTOT (R95pDay) 387 decreased to $0.52(0.53)$ and $0.36(0.36)$ in the spring and autumn seasons, respectively, 388 indicating a decrease in the matching of 3B42 and RG results in seasons with decreased 389 precipitation totals. Mann-Whitney and t-tests showed no significant difference between the 390 means of R95pTOT by 3B42 and RG for R95pTOT in 92 and 98\% of grid cells for winter, $39199 \%$ of the grid cells for spring and 99 and $98 \%$ of grid cells for autumn, respectively, at $5 \%$ 392 significance level. Furthermore, F and Levene tests showed no significant difference between 
393 the variance of R95pTOT obtained by the two datasets in 97 and 92\% of grid cells for winter, 39482 and $79 \%$ of grid cells for spring and 75 and $79 \%$ of grid cells for autumn, respectively, at $3955 \%$ significance level. The matching percentage of the mean and variance tests for the 396 R95pDay index was equal to or slightly higher than the R95pTOT ones. Therefore, it is 397 concluded that there was a very good accordance between means and variances of the 398 obtained 95 percentile extremes by RG and 3B42.

399 As shown in Figure 9, the $95^{\text {th }}$ percentile threshold was used to define extreme events with 400 reference to temporal and spatial neighborhood sizes for winter. The $[1,1]$ time-scale pair 401 (i.e. The former indicates the temporal neighborhood size in days, the latter the spatial 402 neighborhood in pixels) is a substitute for the traditional point-by-point verification, which 403 results in low FSS values. The objective was to mitigate the effect of mismatches due to 404 sampling and difference in the definition of the pair. The objective is achieved with a steady

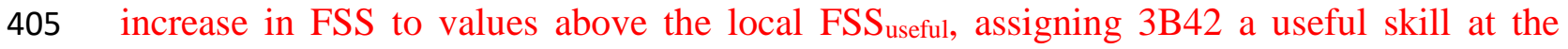
406 aforementioned scales. As Figure 9 indicates, the improvement of results due to increasing 407 spatial neighborhood was greater than the increasing temporal neighborhood, so that for all 408 the temporal neighborhoods, when the spatial neighborhood increased from 1 pixel to 3 409 pixels, the percentage of grid boxes with FSS higher than FSS useful almost doubled. In all 410 combinations of time and space, the southeastern part of province had the lowest values of 411 FSS, even at the scale [7, 7], the pixels in this area had FSS less than FSS useful. The 412 phenomenon may be due to the scarcity of wet days in this area (Figure 5). The same spatial 413 patterns were observed in other seasons as well. However, the percentages of grid cells with 414 useful estimations were lower than those in winter. For example, for spring and autumn at 
$415[1,1]([7,7])$, the percentages of grid cells with useful estimations were $15 \%(87 \%)$ and $5 \%$

416 (79\%), respectively.

417 As explained in Section 2.3.1, RS95pTOT was calculated for each grid cell and season. To

418 be eligible, there must be ten or more precipitation events per season. As Figure 5 shows, the

419 number of eligible years increased from the low rainfall areas in the south-east to northwest

420 areas with highest precipitation totals. Regarding the BR map, in more than 58 percent of the

421 grid cells, 3B42 underestimated the RS95pTOT. The mean BR was 0.98 for the whole

422 province. These were in contrast to the R95pTOT results, where $3 \mathrm{~B} 42$ overestimated

423 R95pTOT in most locations. Also, except for the eastern regions, the spatial consistency of

424 the RS95pTOT was much higher than that of the R95pTOT.

425 4.3. Dry/wet spells

426 In this section, first the results of 3B42 and RG in the estimation of CWD and CDD indices

427 is compared. Then, given the uncertainties for the estimation from RG data, the distribution

428 of TGD is fitted to the number of WP durations in each season. Finally, the average value

429 and the 95th percentile (WPs_mean and WPs_P95, respectively) of the fitted distribution is

430 compared from both RG and 3B42 datasets.

431 As can be observed in Figure 11, the spatial distributions of obtained CDD and CWD by RG

432 and 3B42 datasets overlapped, so that high values of duration indices were observed in

433 northern parts and the low values were located in southern parts of Fars province. It was

434 shown in section 4.1 that 3B42 generally underestimated NWD. A similar trend was observed

435 for CWD in Figure 11, so that the BR value for this parameter was less than 1 in more than 
436

437 grid cells. On the other hand, the average $\mathrm{r}$ for CWD and CDD (0.23 and 0.39, respectively)

438 showed a low correlation between the results of RG and 3B42. Parametric and nonparametric

439

440

441

442

443

444 Because the number of rainy events in the April-September season was low in most of grid

445 cells, it was not possible to fit TGD to these data. As a result, April-September data were excluded from TGD analysis. The area under investigation is a semi-arid region and has a

447 long duration of dry spells, even in the wet season. This means a large value for $\mathrm{N}$ in Equation

448 5, which resulted in lengthening time for fitting method proposed by Zolina et al. (2013).

449 Therefore, obtaining TGD function for DPs data was discarded due to hardware constraints 450 and only TGD distribution calculations were performed for wet spells of the wet season 451 (October-March).

452 Regarding WPs_mean and WPs_P95 in the wet season, Figure 12 shows that 3B42 453 underestimated them in 98 and $89 \%$ of the grid cells, respectively, which was similar to CWD 454 results. The spatially averaged values of $\mathrm{r}$ for these two parameters were 0.29 and 0.23 , 455 respectively, which showed a low correlation between the results of 3B42 and RG. It can be 456 concluded that the use of TGD did not increase the correlation between 3B42 and RG. On 
457 the other hand, the use of TGD did not change the rate of underestimation/overestimation of 458 extreme wet spells significantly.

$459 \quad$ 4.3. Case studies

460 For more detailed comparison between 3B42 and RG results, two grid cells- one with the

461 highest annual rainfall $\left(30.375^{\circ} \mathrm{N}, 51.875^{\circ} \mathrm{E}\right)$ and the other in the low rainfall regions of 462 southeast of the province $\left(27.875^{\circ} \mathrm{N}, 54.375^{\circ} \mathrm{E}\right)$ - were selected. Initially, the time series of

463 winter rainfall were plotted for each location based on RG and 3B42 (Figure 13). Then 464 empirical and TGD histograms of WPs were compared in Figure 14.

465 The first interesting point in Figure 13 is that the Q95 value at point 15 and 140 was under466 and overestimated by 3B42, respectively. This is not related to under/over estimation of total 467 rainfall, so that $\mathrm{BR}$ values for the total rainfall in these grid cells were 0.86 and 0.83 , 468 respectively. The underestimation of wet days at $140(\mathrm{BR}=0.72)$ caused the overestimation 469 of extreme rainfall. Regarding grid cell 15, the opposite is true because the BR value for the 470 NWD was 1.15, Therefore, Q95 was underestimated by 3B42. The interesting point in this 471 figure is that although the R95pTOT had a good correlation coefficient with the precipitation 472 data of rain gauges, the time for the maximum amount of rainfall in the time series had no 473 adaptation in both locations, so that for grid cell No. 15, the maximum daily rainfall was 474 observed in 2002 and 2004 based on RG and 3B42, respectively. This trend also took place 475 at grid cell No. 140, which as RG and 3B42 indicated received the maximum daily rainfall 476 in 2009 and 2006, respectively. Another interesting point is that, regardless of the 
477 over/underestimation of Q95, 3B42 overestimated the maximum daily precipitation during

478 the time series. This trend was observed in $77 \%$ of the examined grid cells.

479 The empirical histograms of wet durations and approximation of these histograms by the

480 TGD for grid cell No. 15 and 140 are indicated in Figure 14. These histograms were obtained

481 from annual time series of WPs in wet seasons. For all WPs, the probability of experimental

482 and the TGD histograms were close to each other except for 1 and 2 days durations at grid

483 cell No. 140. At this location, the WPs frequency with 2 days duration was the highest. A

484 phenomenon that resulted in diffraction of the two histograms based on RG results. As $3 \mathrm{~B} 42$

485 showed, the aforementioned cell received the highest frequency in one-day rainfall,

486 confirming the fact that this region was the rainiest region of the province; therefore, this

487 result is not unexpected. Regarding grid cell No. 140, there was a good agreement between

488 the probabilities of TGD and experimental histograms obtained by RG and 3B42.

\section{5. Discussion}

490 The overall results show that the spatial distribution of extreme indices by 3B42 overlapped

491 with the results of RG. Nastos et al. (2013) showed that high altitudes have increased values

492 of percentile and threshold EPIs compared to coastal regions. According to Nastos et al.

493 (2013), in mountainous regions of the north-western part of Fars higher values of extreme

494 measures were observed compared to southeast parts of the province. Furthermore, the results

495 showed that generally a higher correlation between the results of RG and 3B42 was observed

496 in these regions. The previous studies also documented that there was a high correlation

497 coefficient between RG and 3B42 monthly precipitation over the regions with high amounts 

al., 2016). Among the ETCCDI indices, R95pTOT and Rx1Day had the highest correlation 500 coefficients, while CDD indices had the lowest values with the precipitation data of rain 501 gauges. According to Moazami et al. (2016) the average value of correlation coefficient 502 between 3 B42 precipitation and synoptic rain gauges across Iran is 0.61. Shirvani and 503 Fakharizade-Shirazi (2014) showed that the range of correlation coefficient between the 504 precipitation data of rain gauges and 3B42 was between 0.1-0.7 over Fars province for the 505 period 1998-2011. However, the maximum value of $\mathrm{r}$ across the region for R10mm, CWD, 506 CDD, R95pTOT, R95pDay, and Rx1Day were 0.96, 0.86, 0.91, 0.97, 0.95, and 0.92 in the 507 current study. This shows that the best obtained values of correlation coefficient for 508 precipitation extreme values were higher than those obtained for precipitation data across the 509 area under investigation. Although the researchers presented the results in separate seasons, 510 their findings are also confirmed when mean values of $r$ for annual scale (not shown in the 511 results) for R10mm, CWD, R95pTOT, R95pDay, Rx1Day, which are 0.66, 0.66, 0.80, and 5120.63 respectively, are compared with the results reported by Moazami et al. (2016) in Iran. 513 A probable reason for increased correlation coefficient is that R10mm, CWD, R95pTOT, 514 R95pDay, Rx1Day obtained from seasonal rainfall data and certain date of extreme rainfall 515 occurrence is not a matter of concern in determination of them. This is confirmed when the 516 correlation coefficient of total seasonal rainfall is considered (Figure 5), which was higher 517 than 0.8 for most of the area under investigation.

518 Results from 3B42 indicate that generally R10mm and CWD are underestimated, whereas 519 CDD, R95pDay, R95pTOT and Rx1Day indices are overestimated. Due to lower relative 
520 humidity and higher temperature in semi-arid zones, rain drops may evaporate before 521 reaching the earth surface (Tesfagiorgis et al. 2011). Shirvani and Fakhari Zade Shirazi 522 (2014) show that in north-western part of Fars province- with higher precipitation and 523 altitudes - underestimations of precipitation are observed, whereas in eastern parts- with 524 lower precipitation and altitudes- overestimation of precipitation are observed. Accordingly, 525 overestimation of R10mm, and percentile indices in southeastern parts of the province could 526 be justified. However, in the mountainous regions, where the distance of raindrop travel to 527 earth is shorter, overestimations of these extreme are observed. This is also consistent with 528 the results reported by Moazami et al. (2016) for Iran.

529 To evaluate the prediction of extreme precipitation events by 3B42, a fuzzy method was used.

530 The results showed a better performance for the satellite at the regions with higher amounts 531 of rainfall. Lockhoff et al. (2014) used the same method for the evaluation of GPCP $90^{\text {th }}$ 532 percentile threshold over Europe. They showed that at $[1,1]$ (1 pixel and 1 day window),

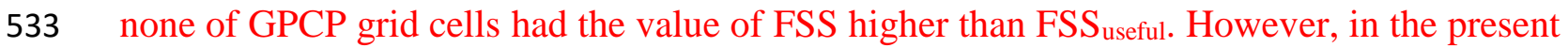
534 study, 20\% of grid cells had the FSS value higher than the criteria, despite the facts that pixel 535 size for 3B42 is one fourth of GPCP and the threshold value for extreme precipitation (Q90) 536 in their study was lower than Q95. AghaKouchak et al., (2011) and Lockhoff et al., (2014) 537 indicated that prediction of detection of precipitation extremes by satellite products decreased 538 as the extreme threshold value increased from Q75 to Q95, which confirms a better 539 performance of 3B42 as compared to GPCP products. The researchers also compared the 540 daily precipitation estimates of 3B42 and GPCP results with each other (not shown), and 541 found a better performance of 3B42. 
542 The index R95pTOT shows the relative contribution of very wet days (i.e. days with 543 precipitation amounts exceeding the $95^{\text {th }}$ percentile) to the total precipitation amounts. This

544 index has often been used to monitor the changes of extreme precipitation amounts. However, 545 the use of this index has been questioned because of its strong year-to-year variations (Zolina 546 et al., 2009; Leander et al., 2014). Leander et al., 2014 showed that R95pTOT is influenced 547 by changes in the mean wet-day precipitation. Since the problem is a matter of concern in 548 trend analysis of extreme precipitation, the researchers also compared the results of $3 \mathrm{~B} 42$ 549 and RG in estimation of the improved index RS95pTOT. The results showed that the spatial 550 consistency between the 3B42 and RG results was very high especially in the north and west 551 parts of Fars with higher values and frequencies of precipitation. The main problem in the 552 estimation of RS95pTOT was that a minimum number of days with precipitation (i.e. 10 553 days) were required. This criterion reduced the eligible years for calculation of RS95pTOT 554 to zero in some south-eastern grid cells of Fars. This makes trend analysis impossible with 555 this extreme index in arid zones. However, this problem was not observed in the northwestern 556 parts of the study area.

557 Any comprehensive analysis of wet/dry durations and extreme precipitation is made possible 558 only when special attention is paid to the extent of data coverage and individual records. In 559 effect, it means that dense precipitation networks are required for such an analysis (Zolina et 560 al., 2009 and 2013). The density of rain gauges in a region is a function of the frequency and 561 the intensity of precipitation. Since southern parts of Fars receive low rainfall, the researchers 562 believe that their findings suffer from low rain gauges density problem. This problem is most 
563 noticeable in the northeastern part of the study area. Hence, the findings are most robust for 564 grid cells that include at least one rain gauge.

\section{6. Conclusion}

566 Research on extreme climate characteristics makes it possible to reveal the spatial and 567 temporal features of a region in the extremeness of precipitation events. In this study, EPIs 568 were obtained from high density rain gauges and TRMM (3B42 V7) datasets. The spatial 569 consistency of 3B42 and RG was good, so that they worked equally well in the northwestern 570 parts of Fars with higher extreme precipitation frequency and amounts. The fuzzy evaluation 571 of results revealed that 3B42 estimations of extreme conditions were useful only in $20 \%$ of

572 grid cells on certain days. This was a better result for a satellite product than the previous 573 studies. The fuzzy results got better, as the window of temporal or spatial neighborhood were 574 extended. An interesting conclusion for the results was that the effect of increasing spatial 575 neighborhood was significantly higher than that of extending temporal window. The 576 percentile precipitation was also obtained based on Weibull distribution to eliminate the 577 seasonal changes of rainfall averages uncertainty. Although the consistency of $3 \mathrm{~B} 42$ and RG 578 results was very good in northwestern parts of Fars, due to lack of required number of wet 579 days in southern parts, the results of this method could not be derived in most of the seasons. 580 This was the main disadvantage of this method in the semi-arid region Fars. For duration 581 indices, another probabilistic method was used based on truncated geometric distribution to 582 remove the uncertainty of probable missing rainfall data. The results indicated that although 583 the consistency between 3B42 and RG datasets was very good, it did not increase 584 significantly in general with the application of the method. It is noteworthy that the 
585 correlation between the results of the two datasets was acceptable and higher than those

586 obtained in previous studies for evaluating TRMM precipitation data over Fars province and

587 Iran. Therefore, with respect to obtained bias ratios for the indices, calibration approaches

588 are recommended to improve satellite results in climate studies.

589 Acknowledgements

590 The researchers thank the Fars Regional Water Organization for providing precipitation data

591 used in this study. They also appreciate the anonymous reviewers who have taken out time

592 to read this manuscript and given them very useful feedbacks. Their critical review improved 593 the clarity and quality of this paper.

595 Supporting Information

596 The following supporting information is available as part of online article:

597 Table S1. List of Meteorological rain gauge stations along with their geographic 598 characteristics and statistics for the respective annual precipitation in period 2000 to 2014.

600 7. References

601

602 1. AghaKouchak, A., Behrangi, A., Sorooshian, S., Hsu, K., \& Amitai, E. (2011).

603 Evaluation of satellite-retrieved extreme precipitation rates across the central United 
604

605

606

607

608

609

610

611

612

613

614

615

616

617

618

619

620

621

622

623

624

States. Journal of Geophysical Research: Atmospheres, 116(D2). https://doi.org/10.1029/2010JD014741.

2. Alijanian, M., Rakhshandehroo, G. R., Mishra, A. K., \& Dehghani, M. (2017). Evaluation of satellite rainfall climatology using CMORPH, PERSIANN-CDR, PERSIANN, TRMM, MSWEP over Iran. International Journal of Climatology, 37(14), 4896-4914. https://doi.org/10.1002/joc.5131.

3. Ashouri, H., Hsu, K. L., Sorooshian, S., Braithwaite, D. K., Knapp, K. R., Cecil, L. D., ... \& Prat, O. P. (2015). PERSIANN-CDR: Daily precipitation climate data record from multisatellite observations for hydrological and climate studies. Bulletin of the American Meteorological Society, 96(1), 69-83. https://doi.org/10.1175/BAMS-D13-00068.1.

4. Awange, J. L., Ferreira, V. G., Forootan, E., Andam-Akorful, S. A., Agutu, N. O., \& He, X. F. (2016). Uncertainties in remotely sensed precipitation data over Africa. International Journal of Climatology, 36(1), 303-323. https://doi.org/10.1002/joc.4346.

5. Azadi, S., \& Karimi-Jashni, A. (2016). Verifying the performance of artificial neural network and multiple linear regression in predicting the mean seasonal municipal solid waste generation rate: A case study of Fars province, Iran. Waste Management, 48, 14-23. https://doi.org/10.1016/j.wasman.2015.09.034.

6. Bharti, V., Singh, C., Ettema, J., \& Turkington, T. A. R. (2016). Spatiotemporal characteristics of extreme rainfall events over the Northwest Himalaya using satellite 
625

626

627

628

629

630

631

632

633

634

635

636

637

638

639

640

641

642

643

644

645

646

647

data. International journal of climatology, 36(12), 3949-3962. https://doi.org/10.1002/joc.4605.

7. Buarque, D. C., de Paiva, R. C. D., Clarke, R. T., \& Mendes, C. A. B. (2011). A comparison of Amazon rainfall characteristics derived from TRMM, CMORPH and the Brazilian national rain gauge network. Journal of Geophysical Research: Atmospheres, 116(D19). https://doi.org/10.1029/2011JD016060

8. Cai, Y., Jin, C., Wang, A., Guan, D., Wu, J., Yuan, F., \& Xu, L. (2016). Comprehensive precipitation evaluation of TRMM 3B42 with dense rain gauge networks in a mid-latitude basin, northeast, China. Theoretical and applied climatology, 126(3-4), 659-671.https://doi.org/10.1007/s00704-015-1598-4.

9. Chen, S., Hong, Y., Gourley, J. J., Huffman, G. J., Tian, Y., Cao, Q., ... \& Li, Z. (2013). Evaluation of the successive V6 and V7 TRMM multisatellite precipitation analysis over the Continental United States. Water Resources Research, 49(12), 8174-8186. https://doi.org/ 10.1002/2012WR012795.

10. Ebert, E. E. (2008). Fuzzy verification of high-resolution gridded forecasts: a review and proposed framework. Meteorological applications, 15(1), 51-64. https://doi.org/10.1002/met.25.

11. Groisman, P. Y., \& Knight, R. W. (2008). Prolonged dry episodes over the conterminous United States: new tendencies emerging during the last 40 years. Journal of Climate, 21(9), 1850-1862. https://doi.org/10.1175/2007JCLI2013.1.

12. Hajani, E., \& Rahman, A. (2018). Characterizing changes in rainfall: a case study for New South Wales, Australia. International Journal of Climatology, 38(3), 14521462. https://doi.org/10.1002/joc.5258 
13. Haylock, M. R., Hofstra, N., Klein Tank, A. M. G., Klok, E. J., Jones, P. D., \& New, M. (2008). A European daily high-resolution gridded data set of surface temperature and precipitation for 1950-2006. Journal of Geophysical Research: Atmospheres, 113(D20). https://doi.org/10.1029/2008JD010201.

14. Heidinger, H., Carvalho, L., Jones, C., Posadas, A., \& Quiroz, R. (2018). A new assessment in total and extreme rainfall trends over central and southern Peruvian Andes during 1965-2010. International Journal of Climatology, 38, e998-e1015. https://doi.org/10.1002/joc.5427.

15. Hong, Y., Gochis, D., Cheng, J. T., Hsu, K. L., \& Sorooshian, S. (2007). Evaluation of PERSIANN-CCS rainfall measurement using the NAME event rain gauge network. Journal of Hydrometeorology, 8(3), 469-482. https://doi.org/ 10.1175/JHM574.1.

16. Hsu, K. L., Gao, X., Sorooshian, S., \& Gupta, H. V. (1997). Precipitation estimation from remotely sensed information using artificial neural networks. Journal of Applied Meteorology, 36(9), 1176-1190. https://doi.org/ 10.1175/15200450(1997)036<1176:PEFRSI>2.0.CO;2.

17. Huffman, G. J., Adler, R. F., Morrissey, M. M., Bolvin, D. T., Curtis, S., Joyce, R., ... \& Susskind, J. (2001). Global precipitation at one-degree daily resolution from multisatellite observations. Journal of hydrometeorology, 2(1), 36-50. https://doi.org/ 10.1175/1525-7541(2001)002<0036:GPAODD>2.0.CO;2.

18. Huffman, G. J., Bolvin, D. T., Nelkin, E. J., Wolff, D. B., Adler, R. F., Gu, G., ... \& Stocker, E. F. (2007). The TRMM multisatellite precipitation analysis (TMPA): 
Quasi-global, multiyear, combined-sensor precipitation estimates at fine scales. Journal of hydrometeorology, 8(1), 38-55. https://doi.org/ 10.1175/JHM560.1.

19. James, G., Witten, D., Hastie, T., \& Tibshirani, R. (2013). An introduction to statistical learning (Vol. 112). New York: springer.

20. Javanmard, S., Yatagai, A., Nodzu, M. I., BodaghJamali, J., \& Kawamoto, H. (2010). Comparing high-resolution gridded precipitation data with satellite rainfall estimates of TRMM_3B42 over Iran. Advances in Geosciences, 25, 119-125. https://doi.org/10.5194/adgeo-25-119-2010.

21. Joyce, R. J., Janowiak, J. E., Arkin, P. A., \& Xie, P. (2004). CMORPH: A method that produces global precipitation estimates from passive microwave and infrared data at high spatial and temporal resolution. Journal of Hydrometeorology, 5(3), 487503. https://doi.org/ 10.1175/1525-7541(2004)005<0487:CAMTPG>2.0.CO;2.

22. Katiraie-Boroujerdy, P. S., Ashouri, H., Hsu, K. L., \& Sorooshian, S. (2017). Trends of precipitation extreme indices over a subtropical semi-arid area using PERSIANNCDR. Theoretical and Applied Climatology, 130(1-2), 249-260. https://doi.org/10.1007/s00704-016-1884-9.

23. Klein Tank, A. M. G., \& Können, G. P. (2003). Trends in indices of daily temperature and precipitation extremes in Europe, 1946-99. Journal of climate, 16(22), 36653680. https://doi.org/10.1175/1520-0442(2003)016<3665:TIIODT>2.0.CO;2

24. Leander, R., Buishand, T. A., \& Tank, A. K. (2014). An alternative index for the contribution of precipitation on very wet days to the total precipitation. Journal of Climate, 27(4), 1365-1378. https://doi.org/10.1175/JCLI-D-13-00144.1. 
25. Li, X., Wang, X., \& Babovic, V. (2018). Analysis of variability and trends of precipitation extremes in Singapore during 1980-2013. International Journal of Climatology, 38(1), 125-141. https://doi.org/10.1002/joc.5165

26. Lockhoff, M., Zolina, O., Simmer, C., \& Schulz, J. (2014). Evaluation of satelliteretrieved extreme precipitation over Europe using gauge observations. Journal of Climate, 27(2), 607-623. https://doi.org/10.1175/JCLI-D-13-00194.1.

27. Manz, B., Páez-Bimos, S., Horna, N., Buytaert, W., Ochoa-Tocachi, B., LavadoCasimiro, W., \& Willems, B. (2017). Comparative Ground Validation of IMERG and TMPA at Variable Spatiotemporal Scales in the Tropical Andes. Journal of Hydrometeorology, 18(9), 2469-2489. https://doi.org/10.1175/JHM-D-16-0277.1

28. McCuen, R. H. (2016). Hydrologic analysis and design (Vol. 3). Prentice Hall.

29. Moazami, S., Golian, S., Hong, Y., Sheng, C., \& Kavianpour, M. R. (2016). Comprehensive evaluation of four high-resolution satellite precipitation products under diverse climate conditions in Iran. Hydrological Sciences Journal, 61(2), 420440. https://doi.org/10.1080/02626667.2014.987675.

30. Najafi, M. R., \& Moazami, S. (2016). Trends in total precipitation and magnitudefrequency of extreme precipitation in Iran, 1969-2009. International Journal of Climatology, 36(4), 1863-1872. https://doi.org/10.1002/joc.4465.

31. Nastos, P. T., Kapsomenakis, J., \& Douvis, K. C. (2013). Analysis of precipitation extremes based on satellite and high-resolution gridded data set over Mediterranean basin. Atmospheric Research, $\quad$ 131, $\quad$ 46-59. https://doi.org/10.1016/j.atmosres.2013.04.009. 
32. Nastos, P. T., Kapsomenakis, J., \& Philandras, K. M. (2016). Evaluation of the TRMM 3B43 gridded precipitation estimates over Greece. Atmospheric Research, 169, 497-514. https://doi.org/10.1016/j.atmosres.2015.08.008.

33. Nordstokke, D. W., Zumbo, B. D., Cairns, S. L., \& Saklofske, D. H. (2011). The operating characteristics of the nonparametric Levene test for equal variances with assessment and evaluation data. Practical Assessment, Research \& Evaluation, 16. Available online: http://pareonline.net/getvn.asp?v=16\&n=5.

34. Ouma, Y. O., Owiti, T., Kipkorir, E., Kibiiy, J., \& Tateishi, R. (2012). Multitemporal comparative analysis of TRMM-3B42 satellite-estimated rainfall with surface gauge data at basin scales: daily, decadal and monthly evaluations. International journal of remote sensing, 33(24), 7662-7684. https://doi.org/10.1080/01431161.2012.701347.

35. Pierre, C., Bergametti, G., Marticorena, B., Mougin, E., Lebel, T., \& Ali, A. (2011). Pluriannual comparisons of satellite-based rainfall products over the Sahelian belt for seasonal vegetation modeling. Journal of Geophysical Research: Atmospheres, 116(D18). https://doi.org/10.1029/2011JD016115

36. Pombo, S., \& de Oliveira, R. P. (2015). Evaluation of extreme precipitation estimates from TRMM in Angola. Journal of Hydrology, 523, 663-679. https://doi.org/10.1016/j.jhydrol.2015.02.014.

37. Prakash, S., Mitra, A. K., Gairola, R. M., Norouzi, H., \& Pai, D. S. (2018). Status of High-Resolution Multisatellite Precipitation Products Across India. In Remote Sensing of Aerosols, Clouds, and Precipitation (pp. 301-314). https://doi.org/10.1016/B978-0-12-810437-8.00014-1. 
736

737

738

739

740

741

742

743

744

745

746

747

748

749

750

751

752

753

754

755

756

757

758

38. Prakash, S., Mitra, A. K., Pai, D. S., \& AghaKouchak, A. (2016a). From TRMM to GPM: How well can heavy rainfall be detected from space?. Advances in Water Resources, 88, 1-7. http://dx.doi.org/10.1016/j.advwatres.2015.11.008.

39. Prakash, S., Mitra, A. K., Rajagopal, E. N., \& Pai, D. S. (2016b). Assessment of TRMM-based TMPA-3B42 and GSMaP precipitation products over India for the peak southwest monsoon season. International Journal of Climatology, 36(4), 16141631. https://doi.org/10.1002/joc.4446.

40. Prat, O. P., \& Nelson, B. R. (2014). Characteristics of annual, seasonal, and diurnal precipitation in the Southeastern United States derived from long-term remotely sensed data. Atmospheric research, 144, 4-20. https://doi.org/10.1016/j.atmosres.2013.07.022.

41. Qiao, L., Hong, Y., Chen, S., Zou, C. B., Gourley, J. J., \& Yong, B. (2014). Performance assessment of the successive Version 6 and Version 7 TMPA products over the climate-transitional zone in the southern Great Plains, USA. Journal of hydrology, 513, 446-456. https://doi.org/10.1016/j.jhydrol.2014.03.040.

42. Raveh-Rubin, S., \& Wernli, H. (2015). Large-scale wind and precipitation extremes in the Mediterranean: a climatological analysis for 1979-2012. Quarterly Journal of the Royal Meteorological Society, 141(691), 2404-2417. https://doi.org/10.1002/qj.2531.

43. Raziei, T., Mofidi, A., Santos, J. A., \& Bordi, I. (2012). Spatial patterns and regimes of daily precipitation in Iran in relation to large-scale atmospheric circulation. International Journal of Climatology, 32(8), 1226-1237. https://doi.org/10.1002/joc.2347 
44. Roberts, N. M., \& Lean, H. W. (2008). Scale-selective verification of rainfall accumulations from high-resolution forecasts of convective events. Monthly Weather Review, 136(1), 78-97. https://doi.org/10.1175/2007MWR2123.1.

45. Shirvani, A., \& Fakhari Zade Shirazi E. (2014). Comparison of ground based observation of precipitation with satellite estimations in Fars province. Journal Agricultural. Meteorology. 2: 1-15 (in Persian).

46. Shrestha, A. B., Bajracharya, S. R., Sharma, A. R., Duo, C., \& Kulkarni, A. (2017). Observed trends and changes in daily temperature and precipitation extremes over the Koshi river basin 1975-2010. International Journal of Climatology, 37(2), 10661083. https://doi.org/10.1002/joc.4761.

47. Skofronick-Jackson, G., Petersen, W. A., Berg, W., Kidd, C., Stocker, E. F., Kirschbaum, D. B., \& Kirstetter, P. E. (2017). The global precipitation measurement (GPM) mission for science and society. Bulletin of the American Meteorological Society, 98(8), 1679-1695. https://doi.org/10.1175/BAMS-D-15-00306.1.

48. Snedecor, G. W. C., \& William, G. (1989). STATISTICAL METHODS/GEORGE W. SNEDECOR AND WILLIAM G. COCHRAN (No. QA276. 12. S6313 1989.).

49. Soufi, M. (2004, July). Morpho-climatic classification of gullies in Fars province, Southwest of IR Iran. In International Soil Conservation Organisation Conference, Brisbane (p. 4).

50. Stedinger, J. R. (1993). Frequency analysis of extreme events. in Handbook of Hydrology. 
51. Tangang, F., Juneng, L., \& Aldrian, E. (2017). Observed changes in extreme temperature and precipitation over Indonesia. International Journal of Climatology, 37(4), 1979-1997. https://doi.org/10.1002/joc.4829.

52. Tarek, M. H., Hassan, A., Bhattacharjee, J., Choudhury, S. H., \& Badruzzaman, A. B. M. (2017). Assessment of TRMM data for precipitation measurement in Bangladesh. Meteorological Applications, 24(3), 349-359. https://doi.org/10.1002/met.1633.

53. Tesfagiorgis, K., Mahani, S. E., Krakauer, N. Y., \& Khanbilvardi, R. (2011). Bias correction of satellite rainfall estimates using a radar-gauge product-a case study in Oklahoma (USA). Hydrology and Earth System Sciences, 15(8), 2631. https://doi.org/10.5194/hess-15-2631-2011.

54. Ushio, T., Sasashige, K., Kubota, T., Shige, S., Okamoto, K. I., Aonashi, K., ... \& Oki, R. (2009). A Kalman filter approach to the Global Satellite Mapping of Precipitation (GSMaP) from combined passive microwave and infrared radiometric data. Journal of the Meteorological Society of Japan. Ser. II, 87, 137-151. https://doi.org/10.2151/jmsj. 87A.

55. Wang, F., Yang, S., Higgins, W., Li, Q., \& Zuo, Z. (2014). Long-term changes in total and extreme precipitation over China and the United States and their links to oceanic-atmospheric features. International Journal of Climatology, 34(2), 286-302. https://doi.org/10.1002/joc.3685.

56. Webster, R., \& Oliver, M. A. (2007). Geostatistics for environmental scientists. John Wiley \& Sons. 
57. Wehbe, Y., Ghebreyesus, D., Temimi, M., Milewski, A., \& Al Mandous, A. (2017). Assessment of the consistency among global precipitation products over the United Arab Emirates. Journal of Hydrology: Regional Studies, 12, 122-135. https://doi.org/10.1016/j.ejrh.2017.05.002.

58. Wilks, D. S. (2011). Statistical methods in the atmospheric sciences (Vol. 100). Academic press.

59. Zhang, X., Alexander, L., Hegerl, G. C., Jones, P., Tank, A. K., Peterson, T. C., ... \& Zwiers, F. W. (2011). Indices for monitoring changes in extremes based on daily temperature and precipitation data. Wiley Interdisciplinary Reviews: Climate Change, 2(6), 851-870. https://doi.org/10.1002/wcc.147.

60. Zhao, T., \& Yatagai, A. (2014). Evaluation of TRMM 3B42 product using a new gauge-based analysis of daily precipitation over China. International Journal of Climatology, 34(8), 2749-2762. https://doi.org/10.1002/joc.3872.

61. Zhao, Y., Xie, Q., Lu, Y., \& Hu, B. (2017). Hydrologic Evaluation of TRMM Multisatellite Precipitation Analysis for Nanliu River Basin in Humid Southwestern China. Scientific Reports, 7(1), 2470. https://doi.org/10.1038/s41598-017-02704-1.

62. Zolina, O., Kapala, A., Simmer, C., \& Gulev, S. K. (2004). Analysis of extreme precipitation over Europe from different reanalyses: a comparative assessment. Global and Planetary Change, 44(1-4), 129-161. https://doi.org/10.1016/j.gloplacha.2004.06.009.

63. Zolina, O., Simmer, C., Belyaev, K., Gulev, S. K., \& Koltermann, P. (2013). Changes in the duration of European wet and dry spells during the last 60 years. Journal of Climate, 26(6), 2022-2047. https://doi.org/10.1175/JCLI-D-11-00498.1. 
825 64. Zolina, O., Simmer, C., Belyaev, K., Kapala, A., \& Gulev, S. (2009). Improving estimates of heavy and extreme precipitation using daily records from European rain gauges. Journal of Hydrometeorology, 10(3), 701-716. https://doi.org/10.1175/2008JHM1055.1.

829 65. Zolina, O., Simmer, C., Gulev, S. K., \& Kollet, S. (2010). Changing structure of 830 European precipitation: longer wet periods leading to more abundant rainfalls. 831 Geophysical Research Letters, 37(6). https://doi.org/10.1029/2010GL042468.

832 66. Zolina, O., Simmer, C., Kapala, A., \& Gulev, S. (2005). On the robustness of the 833 estimates of centennial-scale variability in heavy precipitation from station data over Europe. Geophysical Research $\quad$ Letters, https://doi.org/10.1029/2005GL023231.

836 67. Zolina, O., Simmer, C., Kapala, A., Bachner, S., Gulev, S., \& Maechel, H. (2008). 837 Seasonally dependent changes of precipitation extremes over Germany since 1950 838 from a very dense observational network. Journal of Geophysical Research: 839 Atmospheres, 113(D6). https://doi.org/10.1029/2007JD008393. 
Table 1. Cross-validation results for kriging, Inverse Distance Weighting (IDW), Heylock et al. (2008) method, and Thin Plate Spline (TPS). These results are median values computed from comparing daily observations with estimates employing the mean absolute error as accuracy index.

\begin{tabular}{|c|c|c|c|c|}
\hline \multirow[t]{2}{*}{ Year } & \multicolumn{4}{|l|}{ Method } \\
\hline & Kriging & IDW & Haylock et al. & TPS \\
\hline 2000 & 0.59 & 0.5 & 0.5 & 0.64 \\
\hline 2001 & 0.63 & 0.61 & 0.56 & 0.79 \\
\hline 2002 & 0.35 & 0.29 & 0.26 & 0.41 \\
\hline 2003 & 0.76 & 0.67 & 0.75 & 0.88 \\
\hline 2004 & 0.44 & 0.41 & 0.53 & 0.6 \\
\hline 2005 & 0.54 & 0.43 & 0.43 & 0.62 \\
\hline 2006 & 0.43 & 0.42 & 0.44 & 0.53 \\
\hline 2007 & 0.29 & 0.25 & 0.24 & 0.39 \\
\hline 2008 & 0.28 & 0.22 & 0.21 & 0.33 \\
\hline 2009 & 0.44 & 0.4 & 0.41 & 0.47 \\
\hline 2010 & 0.32 & 0.26 & 0.24 & 0.33 \\
\hline 2011 & 0.78 & 0.76 & 0.7 & 0.89 \\
\hline 2012 & 0.28 & 0.25 & 0.28 & 0.36 \\
\hline 2013 & 0.35 & 0.33 & 0.24 & 0.39 \\
\hline 2014 & 0.33 & 0.28 & 0.25 & 0.43 \\
\hline Mean & $\underline{0.454}$ & $\underline{0.405}$ & $\underline{0.403}$ & $\underline{0.537}$ \\
\hline
\end{tabular}


Table 2. The precipitation extreme indices as proposed by ETCCDI (Zhang et al. 2011).

\begin{tabular}{|c|c|c|c|c|}
\hline Number & Index & Indicator name & Definition & Unit \\
\hline 1 & $\mathrm{R} 10 \mathrm{~mm}$ & Number of heavy precipitation days & Count of days when $P R>=10 \mathrm{~mm}$ & day \\
\hline 2 & $\mathrm{R} 20 \mathrm{~mm}$ & $\begin{array}{l}\text { Number of very heavy precipitation } \\
\text { days }\end{array}$ & Count of days when $P R>=20 \mathrm{~mm}$ & day \\
\hline 3 & CDD & Consecutive dry days & Maximum number of consecutive days with $P R<1 \mathrm{~mm}$ & day \\
\hline 4 & CWD & Consecutive wet days & Maximum number of consecutive days with $P R>=1 \mathrm{~mm}$ & day \\
\hline 5 & SDII & Simple daily intensity index & $\begin{array}{l}\text { Total precipitation divided by number of wet days in the } \\
\text { year }\end{array}$ & $\begin{array}{l}m m \\
\text { day }^{-1}\end{array}$ \\
\hline 6 & R95ртOT & vey wet days & Total PR when RR $>95$ th percentile & $\mathrm{mm}$ \\
\hline 7 & R99pTOT & Extremely wet days & Total PR when RR>99th percentile & $\mathrm{mm}$ \\
\hline 8 & R95pDay & vey wet days & Count of days when RR $>95$ th percentile & day \\
\hline 9 & R99pDay & Extremely wet days & Count of days when RR>99th percentile & day \\
\hline 10 & RX1day & Max 1-day precipitation amount & Maximum 1-day precipitation & $\mathrm{mm}$ \\
\hline 11 & RX5day & Max 5-day precipitation amount & Maximum consecutive 5 -day precipitation & $\mathrm{mm}$ \\
\hline
\end{tabular}


Table 3. Percentage of grid cells with insignificant (Ins) different mean (MW and t-student tests) and variance (Levene and $\mathrm{F}$ tests) at significance level of $5 \%$ and spatiotemporal averaged correlation coefficient for NWD, TOT, and INT at different time scales, 2000-2014.

\begin{tabular}{ccccc}
\hline & & Winter & Spring & Autumn \\
\hline \multirow{4}{*}{ MW Ins. \% } & NWD & 36.1 & 82.8 & 93.5 \\
& TOT & 89.4 & 93.5 & 97.6 \\
& INT & 53.3 & 91.7 & 89.9 \\
\hline \multirow{4}{*}{ t-Studend Ins. } & NWD & 32.0 & 82.3 & 32.0 \\
\% & TOT & 89.9 & 91.7 & 89.9 \\
& INT & 53.3 & 90.5 & 53.3 \\
\hline & NWD & 87.0 & 85.2 & 57.4 \\
\hline \multirow{5}{*}{ Levene Ins. \% } & TOT & 99.4 & 97.0 & 87.0 \\
& INT & 72.2 & 85.2 & 79.3 \\
\hline & NWD & 82.8 & 88.8 & 82.8 \\
& TOT & 97.0 & 97.6 & 97.0 \\
& INT & 50.3 & 77.5 & 50.3 \\
\hline \multirow{5}{*}{ Correlation } & NWD & 0.49 & 0.80 & 0.61 \\
& TOT & 0.91 & 0.90 & 0.72 \\
& INT & 0.67 & 0.60 & 0.54 \\
\hline
\end{tabular}


Table 4. Percentage of grid cells with insignificant (Ins) different mean (MW and t-student tests) and variance (Levene and $\mathrm{F}$ tests) and spatiotemporal averaged correlation coefficient for R10 $\mathrm{mm}$ and Rx1Day at different time scales at siginificance level of $5 \%, 2000-2014$.

\begin{tabular}{|c|c|c|c|c|}
\hline & & Winter & Spring & Autumn \\
\hline \multirow{2}{*}{ MW Ins \% } & $\mathrm{R} 10 \mathrm{~mm}$ & 89.35 & 89.94 & 100 \\
\hline & Rx1Day & 88.76 & 95.86 & 100 \\
\hline \multirow{2}{*}{$\begin{array}{l}\text { t-Studend } \\
\text { Ins \% }\end{array}$} & $\mathrm{R} 10 \mathrm{~mm}$ & 88.17 & 89.35 & 100 \\
\hline & Rx1Day & 87.57 & 95.27 & 98.22 \\
\hline \multirow{2}{*}{ Levene Ins \% } & $\mathrm{R} 10 \mathrm{~mm}$ & 92.31 & 94.08 & 82.25 \\
\hline & Rx1Day & 84.62 & 95.86 & 93.49 \\
\hline \multirow{2}{*}{ F test Ins \% } & $\mathrm{R} 10 \mathrm{~mm}$ & 86.39 & 95.27 & 86.98 \\
\hline & Rx1Day & 71.6 & 94.08 & 94.67 \\
\hline & $\mathrm{R} 10 \mathrm{~mm}$ & 0.72 & 0.75 & 0.63 \\
\hline & Rx1Day & 0.62 & 0.69 & 0.6 \\
\hline \multirow{2}{*}{$B R$} & $\mathrm{R} 10 \mathrm{~mm}$ & 0.82 & 1.02 & 1.02 \\
\hline & Rx1Day & 1.16 & 1.08 & 1.3 \\
\hline
\end{tabular}


Table S1. List of Meteorological rain gauge stations along with their geographic characteristics and statistics for the respective annual precipitation in period of 2000 to 2014.

\begin{tabular}{|c|c|c|c|c|c|c|c|c|}
\hline No & Station & $\begin{array}{l}\text { Lon } \\
\left({ }^{\circ}\right)\end{array}$ & $\begin{array}{l}\text { Lat } \\
\left({ }^{\circ}\right)\end{array}$ & Alt (m) & $\begin{array}{l}\text { Mean } \\
\text { Annual } \\
(\mathrm{mm})\end{array}$ & Min & Max & $\begin{array}{l}\text { Standard } \\
\text { Deviation }\end{array}$ \\
\hline 1 & Goshnegan-Maharloo & 52.88 & 29.5 & 1440 & 452 & 67.8 & 228.6 & 101.4 \\
\hline 2 & Mooroozeh & 51.9 & 30.17 & 1946 & 1048.5 & 271 & 575.6 & 199.3 \\
\hline 3 & Barghan & 52.02 & 30.21 & 2109 & 1175.5 & 286.5 & 625 & 228.3 \\
\hline 4 & Batoon & 51.32 & 30.24 & 751 & 948.5 & 211.8 & 533.4 & 203.2 \\
\hline 5 & Mal-Ghayedi & 52.02 & 30.04 & 1639 & 951 & 226 & 481.9 & 179.7 \\
\hline 6 & Babamonir & 51.21 & 30.08 & 1033 & 826 & 137 & 433.2 & 174 \\
\hline 7 & Booshigan-Kazeroon & 51.51 & 29.73 & 735 & 706 & 116.5 & 403 & 146.3 \\
\hline 8 & Kazeroon & 51.66 & 29.61 & 841 & 857.5 & 130.2 & 416.3 & 177.3 \\
\hline 9 & Dasht-Arzhan & 51.99 & 29.66 & 2029 & 1436.5 & 353 & 729 & 276 \\
\hline 10 & Nargesi & 52.05 & 29.26 & 933 & 607 & 88 & 288.7 & 120.5 \\
\hline 11 & Jareh & 51.98 & 29.25 & 868 & 702.5 & 103 & 314.8 & 141.2 \\
\hline 12 & Farashband & 52.08 & 28.84 & 805 & 539 & 53.5 & 225.1 & 110 \\
\hline 13 & Chiti-Boorki & 51.31 & 29.6 & 490 & 703 & 87 & 317.2 & 144.7 \\
\hline 14 & Ghaemieh & 51.6 & 29.84 & 915 & 1014.5 & 162.5 & 522.7 & 203.1 \\
\hline 15 & Khormayek & 52.05 & 28.77 & 781 & 523 & 49 & 216.5 & 109.1 \\
\hline 16 & Sarmashhad & 51.71 & 29.29 & 822 & 660.5 & 81.5 & 280.5 & 134.1 \\
\hline 17 & Band-Bahman & 52.57 & 29.21 & 1597 & 872.5 & 128.5 & 401.8 & 181.9 \\
\hline 18 & Aliabad-Khafr & 53.03 & 29.02 & 1368 & 590 & 63.5 & 258.9 & 132.2 \\
\hline 19 & Karian & 53.54 & 28.15 & 843 & 382.5 & 68.5 & 194 & 91.2 \\
\hline 20 & Fasa & 53.65 & 28.93 & 1370 & 560.9 & 57.4 & 245.4 & 124.4 \\
\hline 21 & Soroor & 53.75 & 28.47 & 1347 & 758 & 93.5 & 324.8 & 160.8 \\
\hline 22 & Tang-Karzin-Dohbe & 53.13 & 28.45 & 712 & 502 & 94.5 & 245 & 105.9 \\
\hline 23 & Mobarakabad & 53.33 & 28.36 & 715 & 493 & 55 & 221.9 & 114.2 \\
\hline 24 & Hanifghan & 52.56 & 29.09 & 1598 & 851 & 133 & 391.4 & 169.7 \\
\hline 25 & Tongab-Firoozabad & 52.54 & 28.91 & 1376 & 971.5 & 113 & 405 & 192.3 \\
\hline 26 & Roniz-Olya & 53.78 & 29.2 & 1597 & 564 & 72.5 & 223 & 124.8 \\
\hline 27 & Jahrom & 53.56 & 28.5 & 1047 & 497 & 69.5 & 245.7 & 111.7 \\
\hline 28 & Khanzenyan & 52.15 & 29.67 & 1966 & 738 & 210.5 & 440.8 & 143.8 \\
\hline 29 & eej & 54.24 & 29.03 & 1495 & 339 & 43 & 216.3 & 90.6 \\
\hline 30 & Baba-arab & 53.8 & 28.59 & 1160 & 432.5 & 65.8 & 190.5 & 100.2 \\
\hline 31 & Khoorab & 52.32 & 28.6 & 606 & 468 & 38.5 & 222.3 & 109.9 \\
\hline 32 & Hakkan & 53.42 & 28.62 & 966 & 592.5 & 88 & 271.3 & 127.8 \\
\hline 33 & Dezhgah & 52.39 & 28.2 & 223 & 283 & 35.9 & 143.6 & 68.8 \\
\hline 34 & Khorgheh & 52.38 & 28.91 & 1590 & 1163.5 & 142 & 501.9 & 226.4 \\
\hline 35 & Dahvieh & 52.74 & 28.68 & 1372 & 721 & 92 & 346.4 & 146.1 \\
\hline 36 & Sheshdeh-Gharebolagh & 53.96 & 28.96 & 1411 & 537.5 & 64.5 & 252 & 110.5 \\
\hline 37 & Hengam & 52.6 & 28.37 & 560 & 445 & 61.5 & 217.4 & 97.6 \\
\hline 38 & Ooz & 54.01 & 27.77 & 969 & 296.5 & 61.5 & 186.4 & 73.7 \\
\hline 39 & Jookan & 52.58 & 29.04 & 1528 & 767.5 & 110 & 344.9 & 153.5 \\
\hline
\end{tabular}




\begin{tabular}{|c|c|c|c|c|c|c|c|c|}
\hline 40 & Dehkooyeh & 54.42 & 27.86 & 1010 & 238 & 59.5 & 156 & 63.4 \\
\hline 41 & Hasanabad-Marmeh & 53.91 & 28.07 & 873 & 276 & 37 & 159.6 & 83.1 \\
\hline 42 & Garebayegan & 53.92 & 28.61 & 1154 & 401 & 64 & 198.2 & 101.1 \\
\hline 43 & Myanjangal & 53.42 & 29.16 & 1713 & 897 & 104 & 352 & 189.1 \\
\hline 44 & Dehrood-Firoozabad & 52.57 & 28.62 & 903 & 462.5 & 53 & 221.6 & 108 \\
\hline 45 & Gavazoon & 54.45 & 28.82 & 1239 & 523.2 & 94.4 & 265.3 & 108.4 \\
\hline 46 & Dehkheir-Jannatshahr & 54.68 & 28.66 & 1173 & 370 & 85.5 & 221.8 & 95.8 \\
\hline 47 & Darbeghaleh & 54.38 & 28.95 & 1422 & 519 & 96.3 & 257.9 & 111.4 \\
\hline 48 & Hajiabad-Zarindasht & 54.43 & 28.35 & 1067 & 298 & 57 & 186.5 & 80.1 \\
\hline 49 & Forg & 55.21 & 28.28 & 928 & 253.5 & 47 & 147.5 & 58.7 \\
\hline 50 & Edareh-Lar & 54.31 & 27.65 & 841 & 248.1 & 59 & 154 & 63.9 \\
\hline 51 & Lamerd & 53.16 & 27.34 & 450 & 351.8 & 76.5 & 183.6 & 88.2 \\
\hline 52 & Layezangan & 54.98 & 28.67 & 1967 & 598 & 151 & 423.5 & 141.3 \\
\hline 53 & Menj & 53.9 & 30.36 & 1865 & 237.5 & 50 & 126.1 & 59.2 \\
\hline 54 & Mazayjan-Bavanat & 53.81 & 30.3 & 2128 & 401.5 & 61.5 & 201 & 91 \\
\hline 55 & Meshkan & 54.33 & 29.48 & 2215 & 523.5 & 86.5 & 268.2 & 114.1 \\
\hline 56 & Sadegh-Abad & 52.32 & 31.16 & 2361 & 461 & 38.5 & 206.2 & 97.2 \\
\hline 57 & Soorian & 53.63 & 30.47 & 2136 & 424.5 & 75 & 184.1 & 100.9 \\
\hline 58 & Mehrabad-Ramjerd & 52.7 & 29.97 & 1606 & 732.3 & 138.3 & 329.7 & 146.8 \\
\hline 59 & Jamalbeig & 51.95 & 30.61 & 2010 & 784 & 203.5 & 479.7 & 165.9 \\
\hline 60 & Chamriz & 52.1 & 30.47 & 1810 & 833 & 157 & 415.7 & 168.3 \\
\hline 61 & Bidkol & 52.63 & 30.17 & 1626 & 744 & 145.5 & 361 & 152.6 \\
\hline 62 & Kaftar & 52.73 & 30.53 & 2342 & 971 & 191.5 & 471.9 & 207 \\
\hline 63 & Jahanabad-Bakhtegan & 53.86 & 29.71 & 1577 & 481.4 & 82 & 216.6 & 98.2 \\
\hline 64 & Arsanjan & 53.32 & 29.92 & 1648 & 603.5 & 75 & 268.8 & 144.6 \\
\hline 65 & Dashtbal & 52.98 & 30 & 1673 & 710 & 117.8 & 311.6 & 146.5 \\
\hline 66 & Ghalat-Shiraz & 52.35 & 29.84 & 1881 & 1090 & 222 & 530.2 & 210.9 \\
\hline 67 & Polekhan & 52.77 & 29.85 & 1493 & 664.5 & 92.5 & 276.3 & 139.9 \\
\hline 68 & Shiraz & 52.53 & 29.63 & 1522 & 730.5 & 129.9 & 333.2 & 147.4 \\
\hline 69 & Dobaneh & 52.78 & 29.42 & 1489 & 855.5 & 137.5 & 359 & 175.5 \\
\hline 70 & Khosroshirin & 52.01 & 30.9 & 2342 & 702.5 & 127.5 & 382.3 & 145.2 \\
\hline 71 & Garde-Estahban & 53.88 & 29.16 & 1698 & 841.5 & 96.5 & 341.6 & 191.6 \\
\hline 72 & Doshmanziari & 52.37 & 30.08 & 1663 & 781 & 144 & 385.5 & 159.4 \\
\hline 73 & Choobkhale & 51.89 & 30.55 & 2056 & 1318.5 & 377.5 & 845.8 & 270 \\
\hline 74 & Abade-Tashk & 53.73 & 29.81 & 1604 & 532 & 77 & 234.3 & 121.5 \\
\hline 75 & $\begin{array}{l}\text { Ahmadabad- } \\
\text { Chahardangeh }\end{array}$ & 52.69 & 30.39 & 2275 & 744.5 & 134.5 & 332.1 & 160.5 \\
\hline 76 & Sahlabad & 53.9 & 29.26 & 1518 & 403 & 52 & 181.2 & 84.4 \\
\hline 77 & Doroodzan & 52.44 & 30.21 & 1662 & 786 & 193 & 423.9 & 160.4 \\
\hline 78 & Madarsoleiman & 53.18 & 30.19 & 1868 & 610.5 & 120 & 305.3 & 133.3 \\
\hline 79 & Estahban & 54.05 & 29.12 & 1745 & 704 & 82.9 & 299.7 & 157.3 \\
\hline 80 & Hosseinabad-Sarab & 52.36 & 29.97 & 1695 & 747.5 & 168 & 395.6 & 143.5 \\
\hline 81 & Neiriz & 54.35 & 29.19 & 1657 & 378 & 57 & 164.6 & 78.1 \\
\hline 82 & Sarvestan & 53.22 & 29.28 & 1570 & 432 & 60.5 & 205.8 & 90.7 \\
\hline 83 & Emamzadeh-Esmaeel & 52.59 & 30.32 & 1842 & 859.5 & 193 & 459.7 & 172.4 \\
\hline
\end{tabular}




\begin{tabular}{lcccccccc}
84 & Dashtak & 52.47 & 30.29 & 2031 & 784 & 219 & 447.3 & 154.6 \\
85 & Horgan & 54.47 & 29.11 & 1898 & 649.5 & 84.5 & 279.3 & 145.2 \\
86 & Kholar & 52.24 & 29.97 & 2056 & 1112 & 287 & 574.7 & 228.6 \\
87 & Sedeh & 52.16 & 30.72 & 2198 & 829.5 & 136.7 & 446 & 184 \\
88 & Komahr & 51.88 & 30.45 & 2354 & 1789 & 431 & 1007.3 & 367.6 \\
89 & Poltalkh & 53.43 & 29.46 & 1592 & 359.5 & 55 & 152.1 & 77.5 \\
90 & Fenjan & 53.49 & 30.39 & 2376 & 657 & 135 & 327.7 & 137 \\
\hline
\end{tabular}



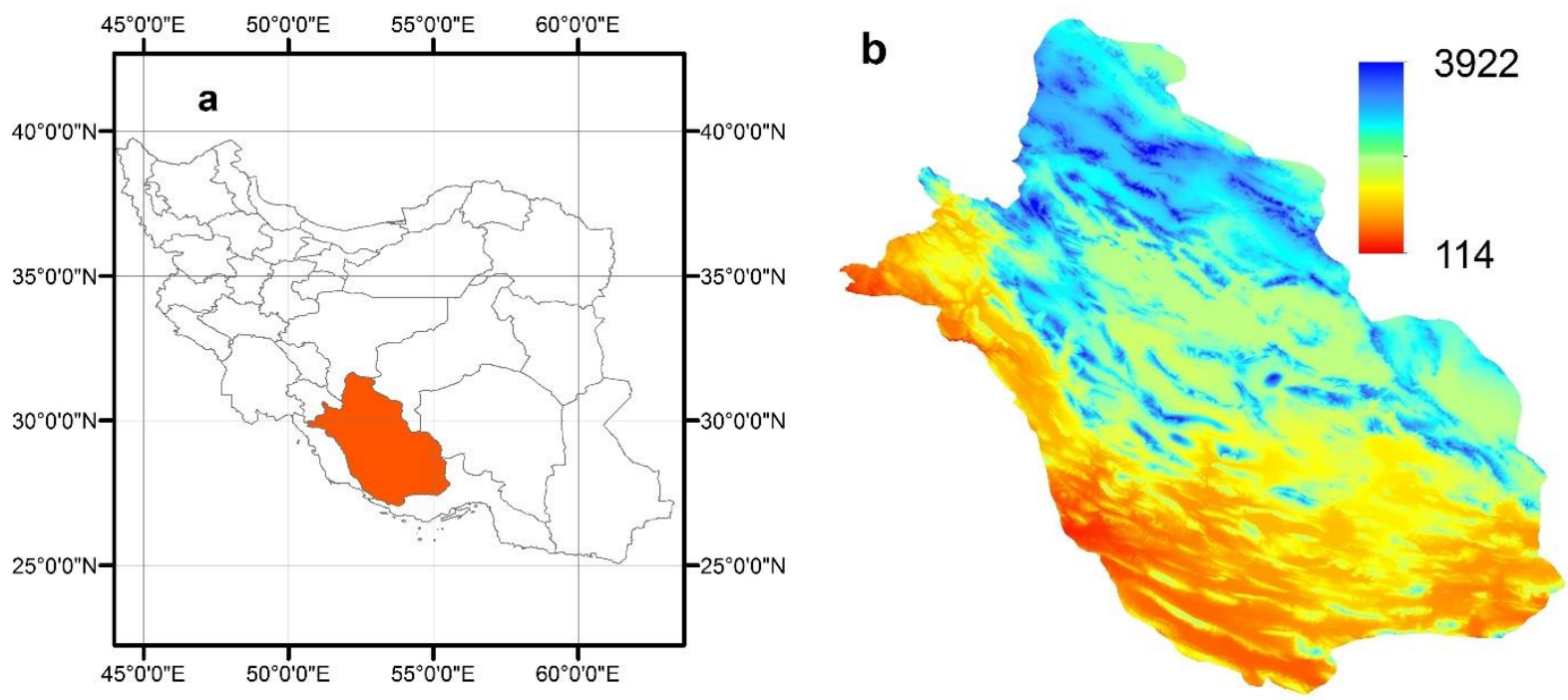

Figure 1. (a) Geographic location of Fars province in I.R. of Iran; (b) Elevation map of Fars province (m). 

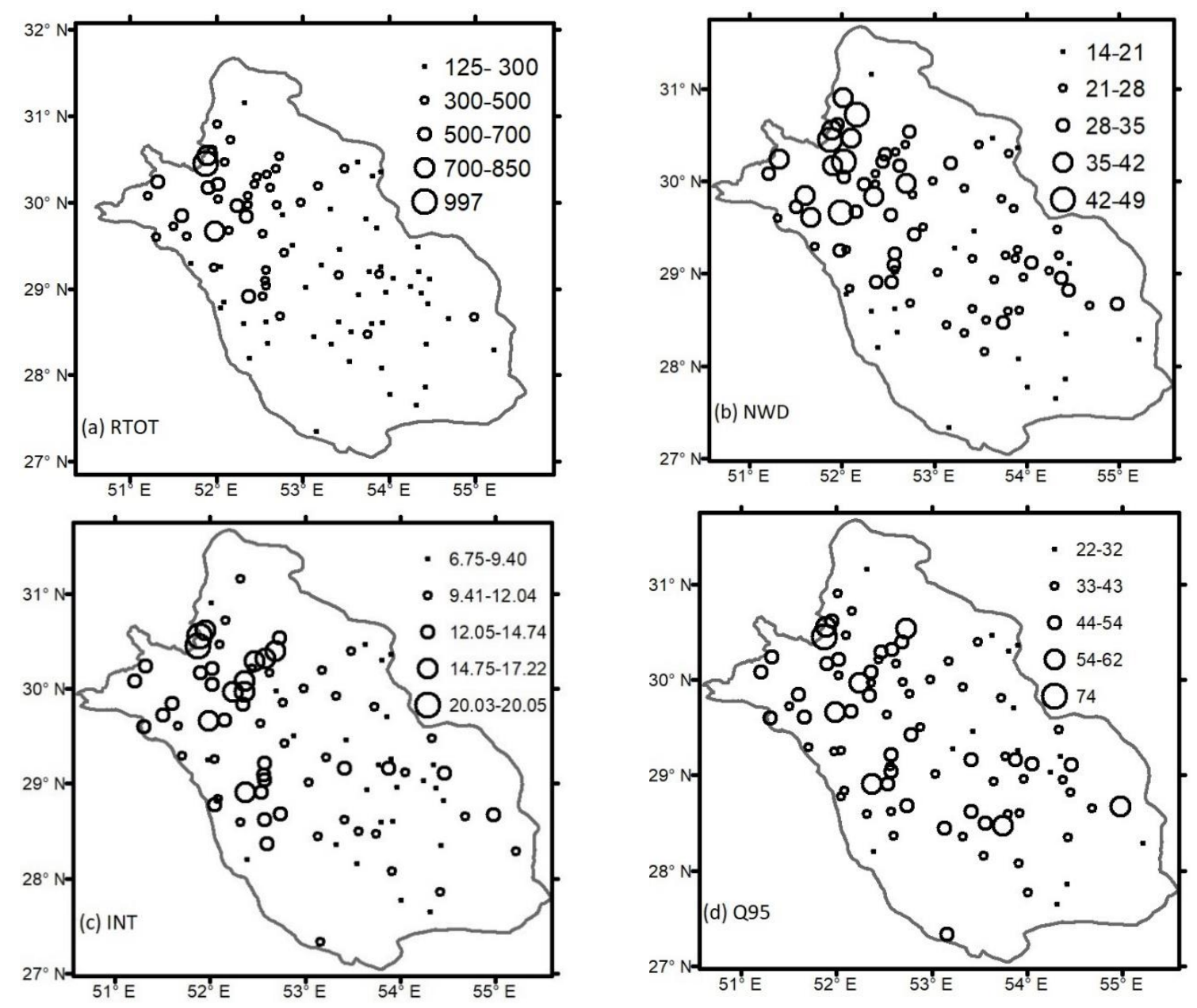

Figure 2. (a) Average of annual precipitation (RTOT, mm), (b) mean number of wet days in a year (NWET, day) (c) average of annual precipitation over all wet days (INT, mm day ${ }^{-1}$ ), (d) and 95th percentile from the empirical (wet day) distribution functions (Q95, mm), for the rain gauges of Far province, 2000-2014. 


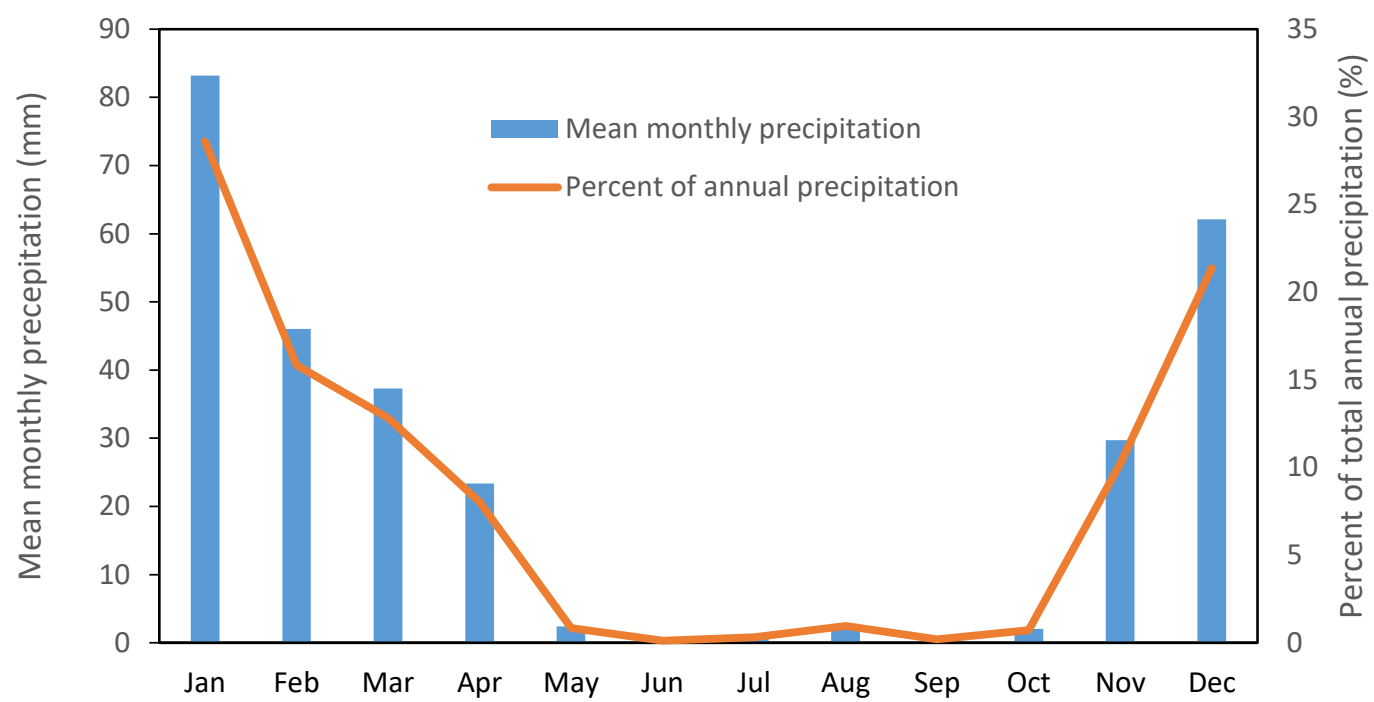

Figure 3. The climatological mean of monthly precipitation $(\mathrm{mm})$ and the percentage of annual precipitation across the Fars province, 2000 - 2014. 


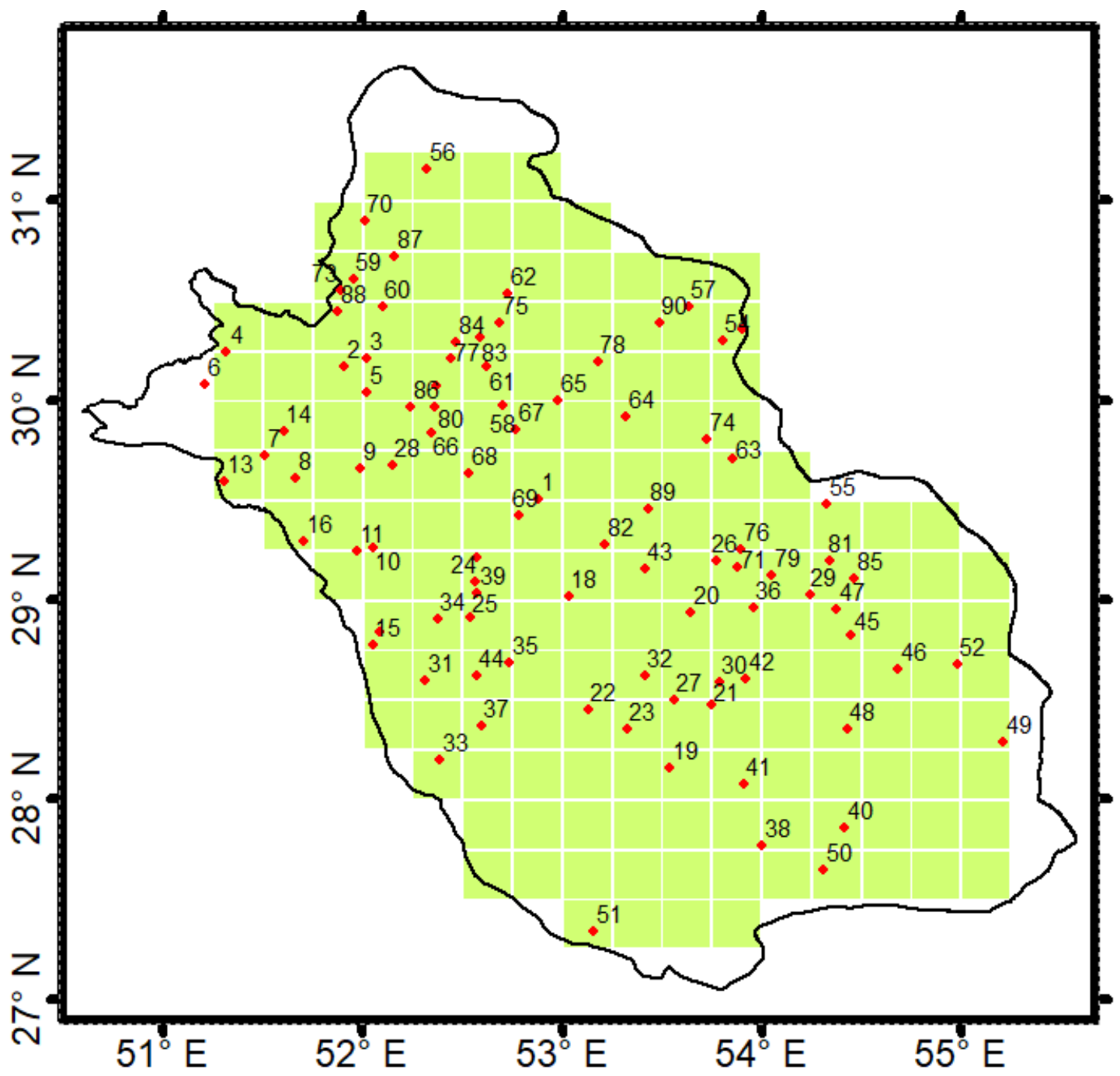

Figure 4. Geographic location of rain gauges and 3B42 grid cells across Fars province. 

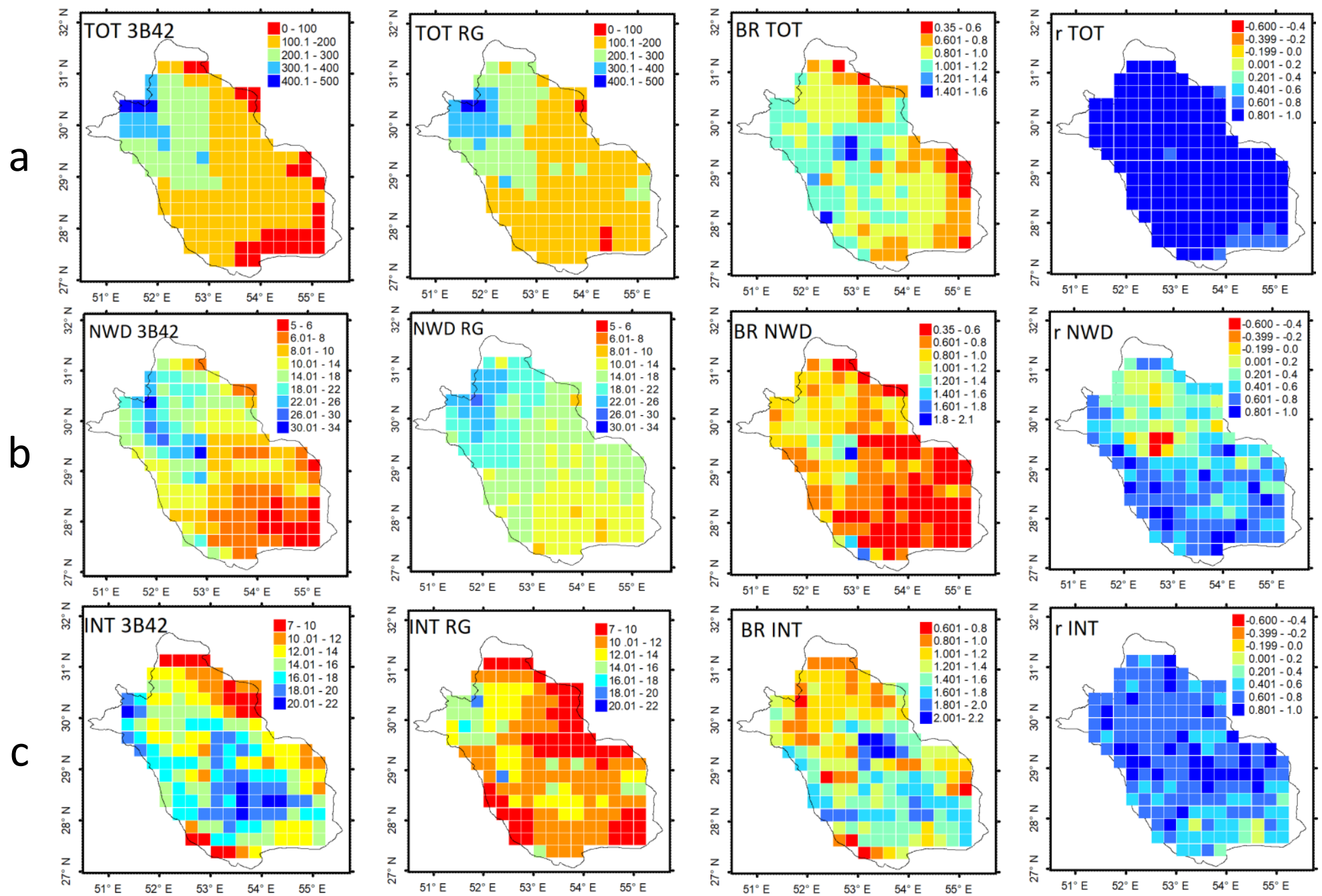

Figure 5. (a) Climatological mean total precipitation ( $\mathrm{mm}$ ), (b) mean number of wet days (day/season), (c) mean wet-day intensity (mm/day) based on winter season (DJF) of the entire time period (2000-2014) for 3B42 estimates (first column), RG results (second column), bias ratio (3B42/RG, third column), and Pearson correlation coefficient (forth column). 
a
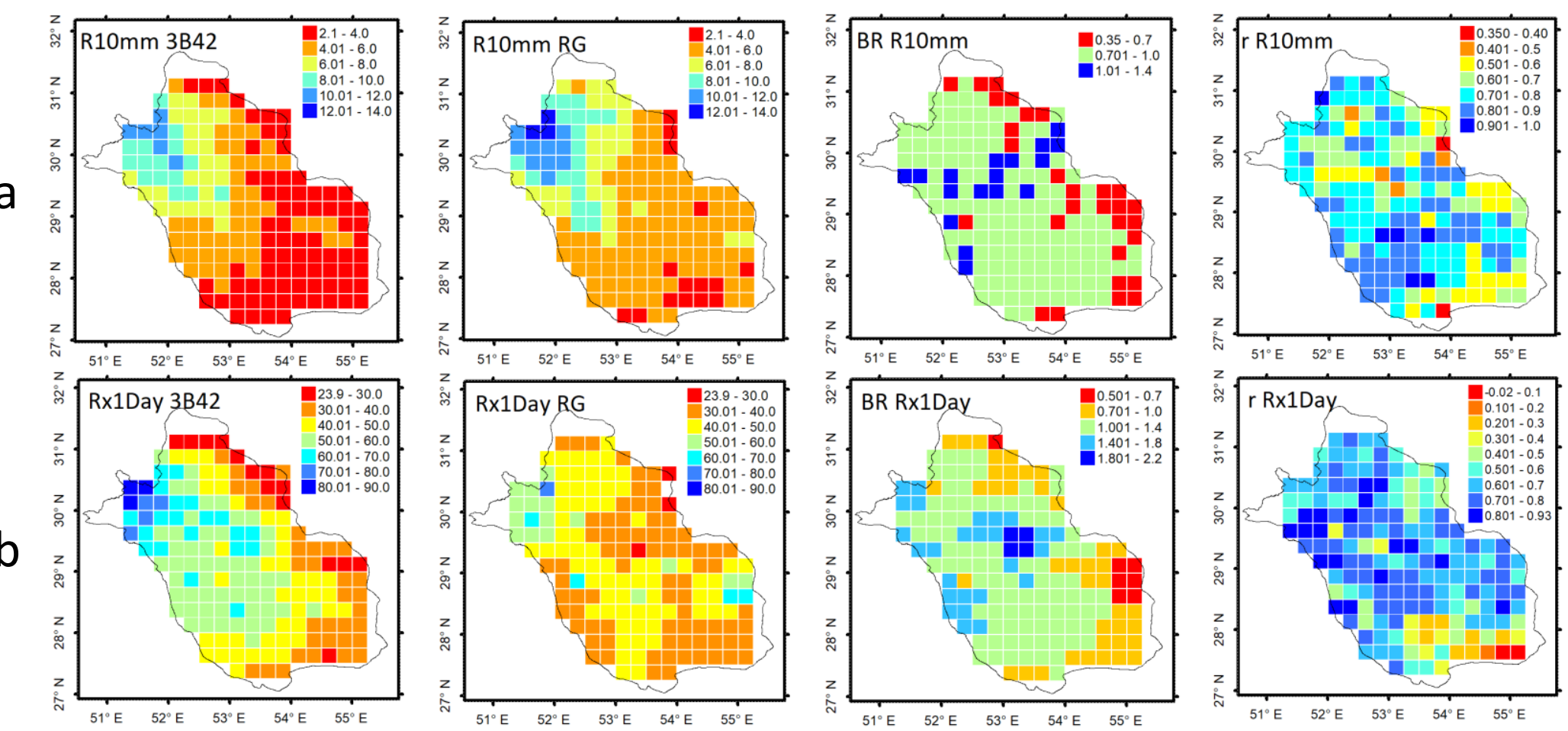

Figure 6. (a) Mean R10mm and (b) mean Rx1Day based on winter season (DJF) of the entire time period (2000-2014) for 3B42

estimates (first column), RG results (second column), bias ratio (3B42/RG, third column), and Pearson correlation coefficient (forth column). 

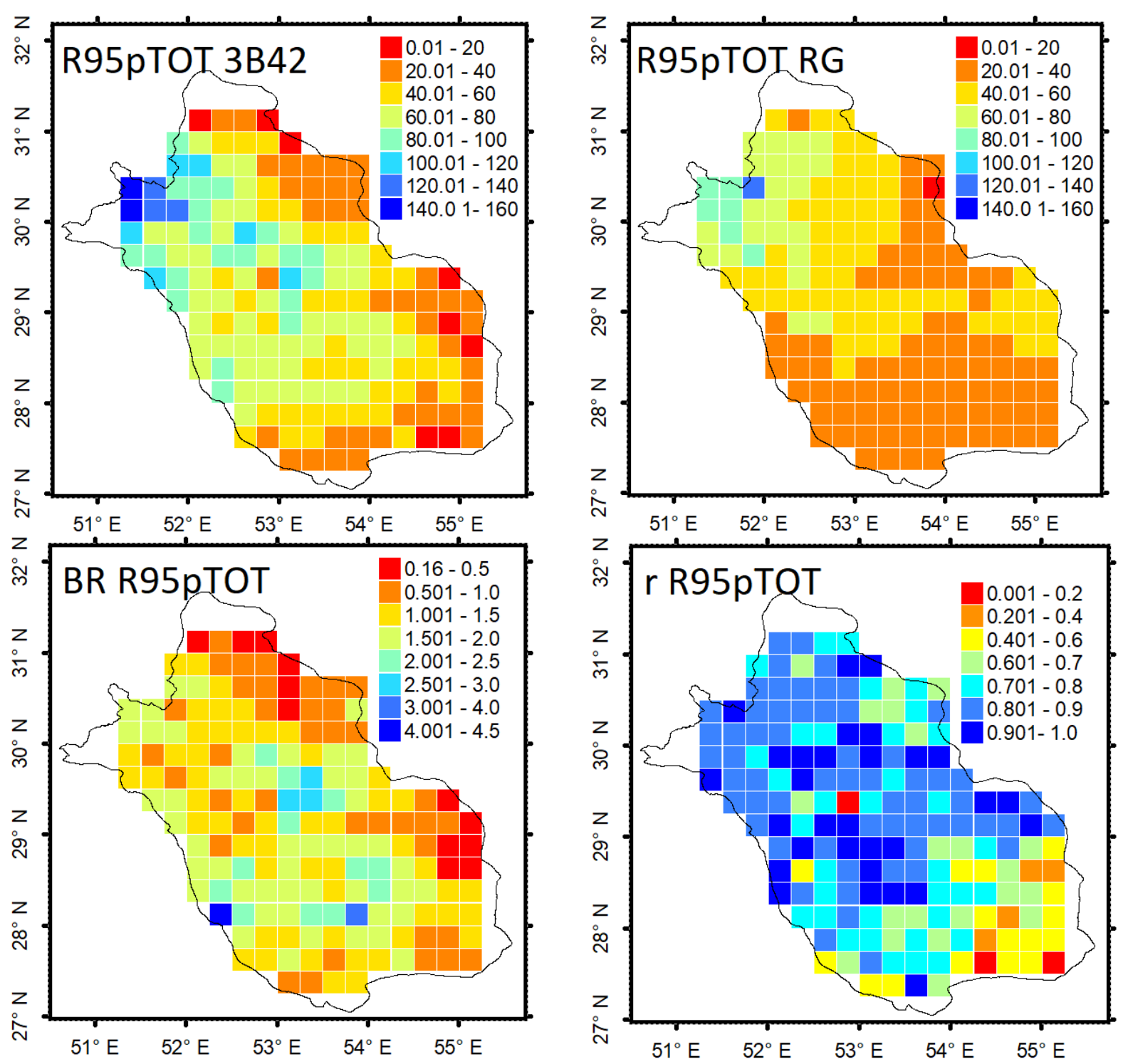

Figure 7. Spatial distribution of R95pTOT obtained from $3 \mathrm{~B} 42$ and RG with bias ratio (BR) and Pearson correlation coefficient (r) for winter (DJF) for the period 2000-2014. 

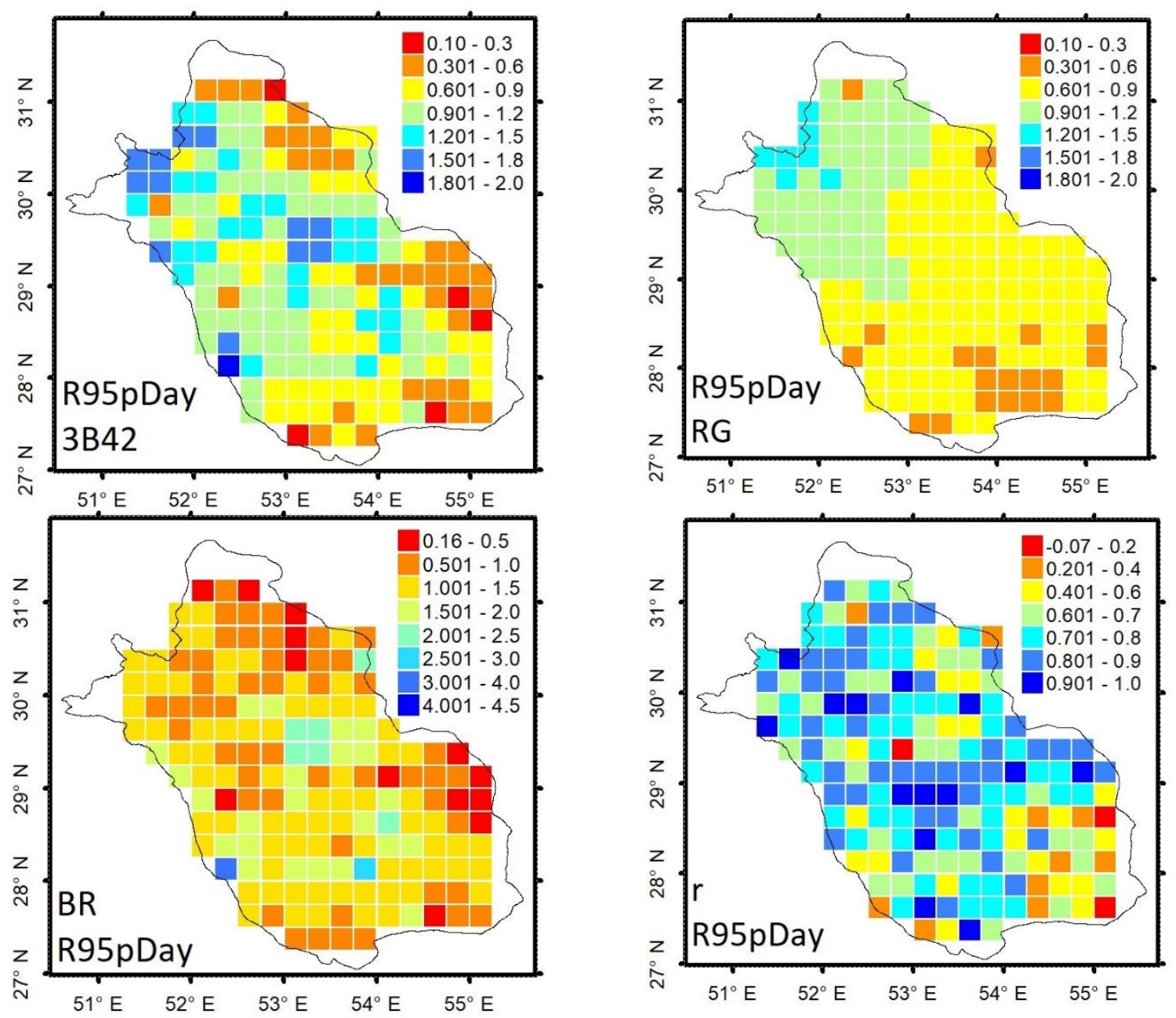

Figure 8. Spatial distribution of R95pDay obtained from 3B42 and RG with bias ratio (BR) and Pearson correlation coefficient (r) for winter (DJF) for the period 2000-2014. 

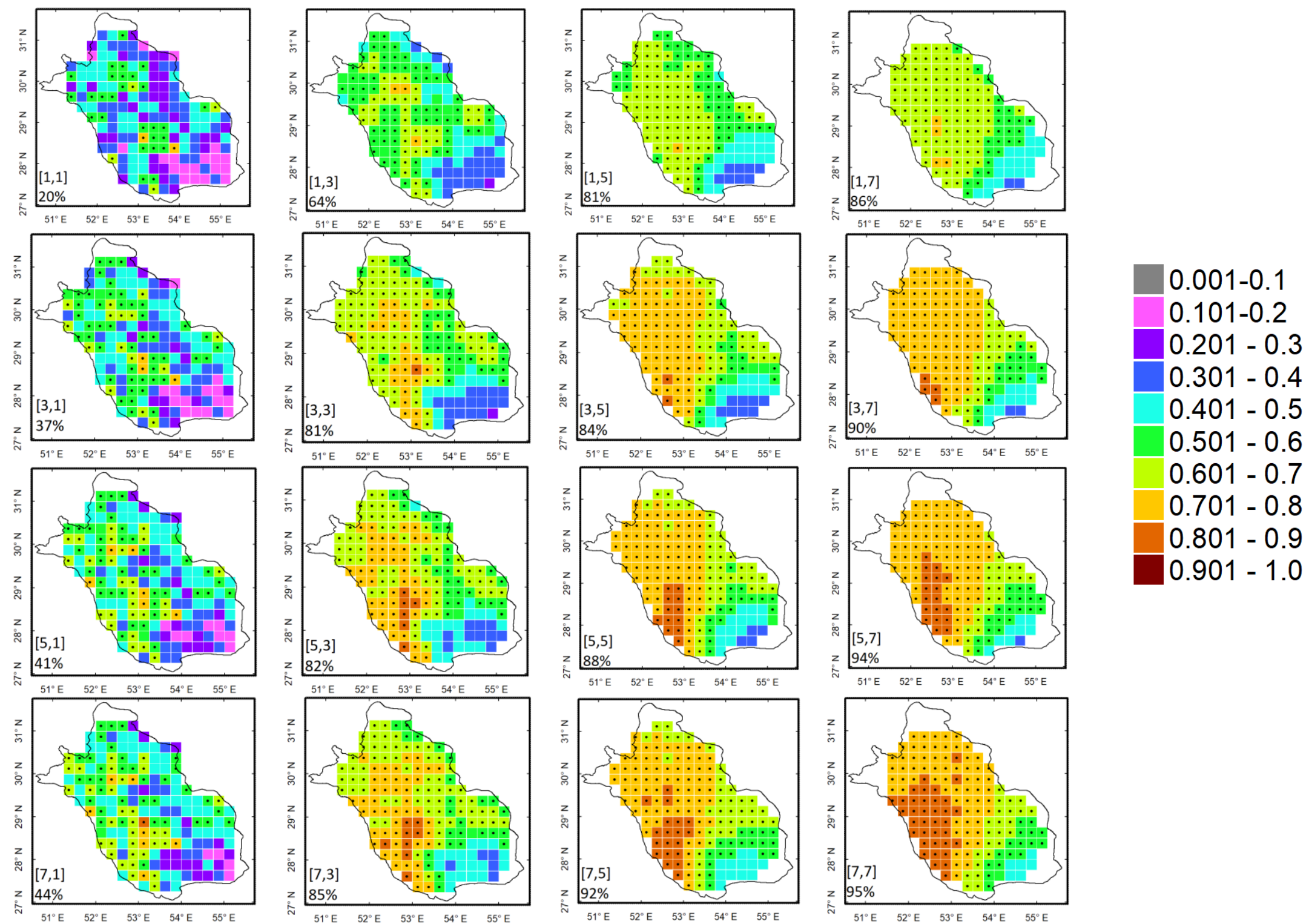

Figure 9. FSS based on the 95th percentile threshold for the winter season (DJF) as a function of increasing temporal (1,3,5, and 7 days; first numbers in brackets) and spatial (1,3,5, and 7 pixels; second numbers in brackets) size of the neighborhood. The numbers beside \% sign indicate the relative number of grid boxes (\%) with FSS values exeedind the local FSS useful $_{\text {and }}$ the points in the maps indicate the location of these pixels. 

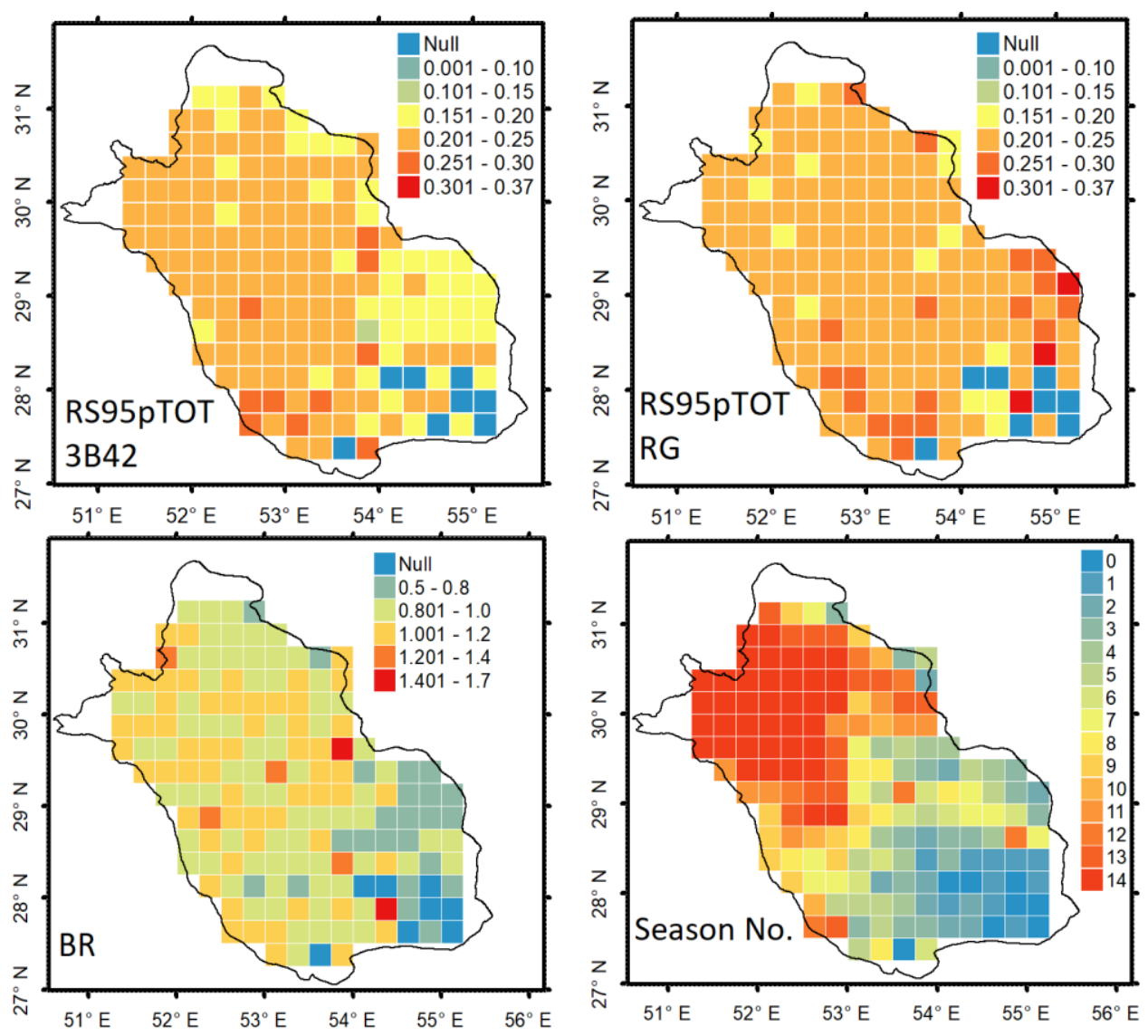

Figure 10. Climatological (2000-2014) mean of RS95pTOT for winter (DJF) with coresponding values of mean bias ratio (BR) and number of cosiderderd winter (DJF) seasons. 

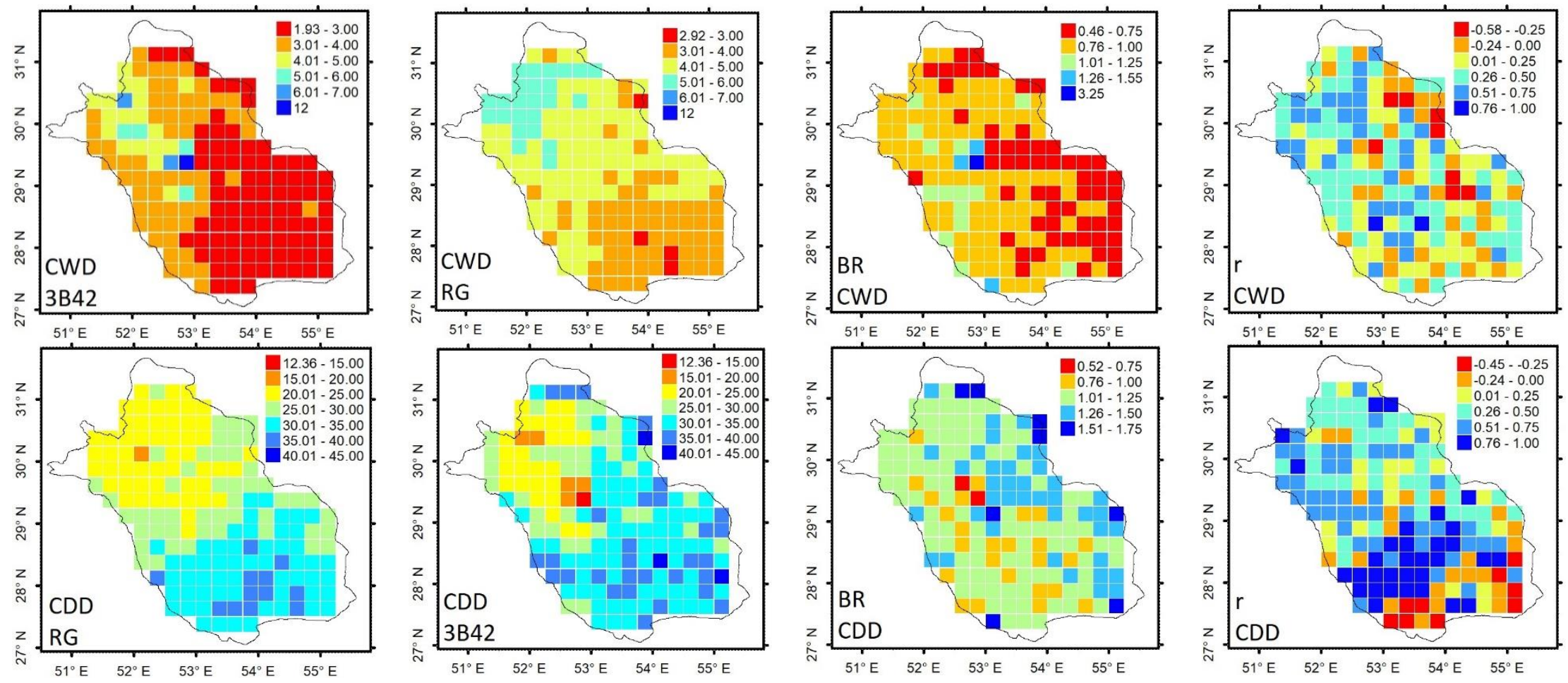

Figure 11. Spatial variation of mean CDD and CWD, with bias ratio (BR), and Pearson correlation coefficient (r) for each, the values are averages for the wet season (October-March) 2000-2014. 

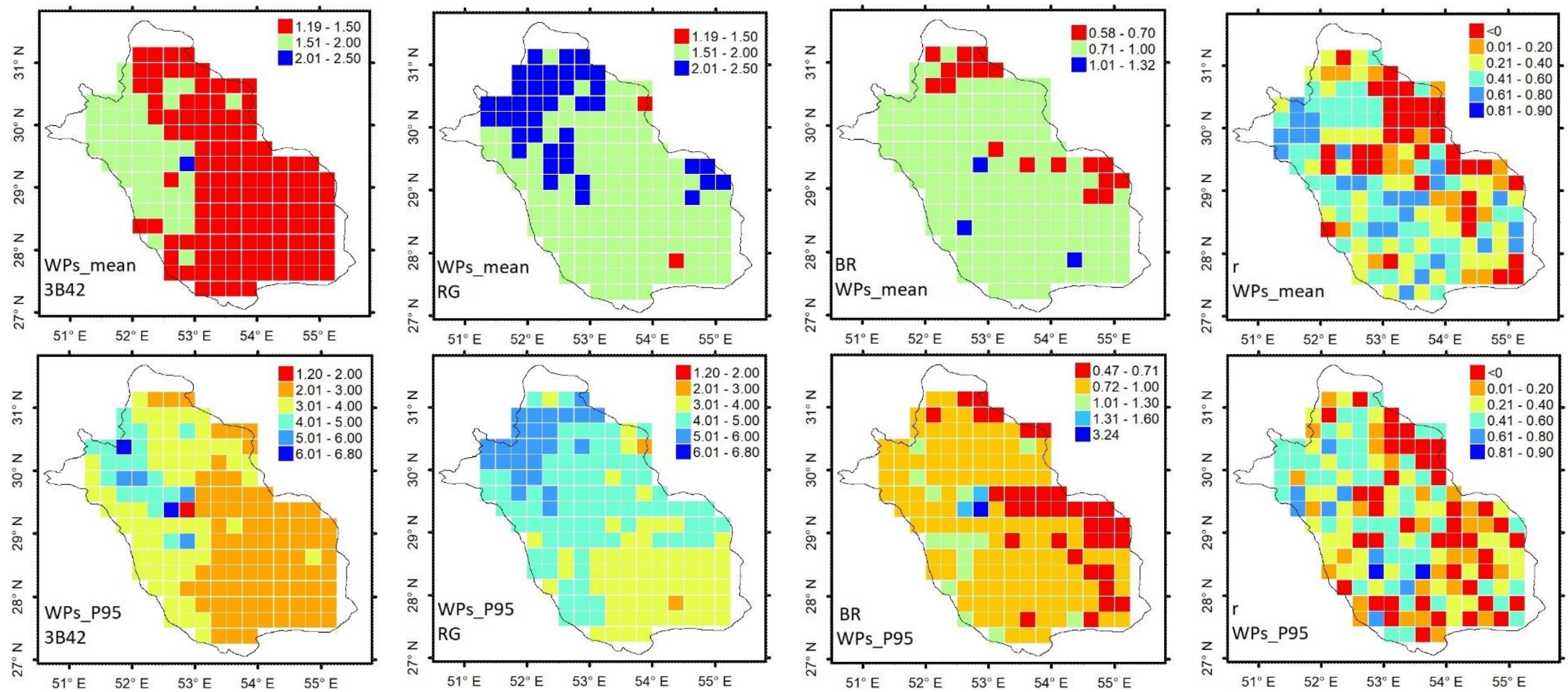

Figure 12. Distribution of the mean duration (WPs_mean), 95 percentile (WPs_P95) of wet spells obtained from TGD based on 3B42 and RG datasets and bias ratio (BR) Pearson correlation coefficient (r), all maps are for wet season (October-March), 20002014. 

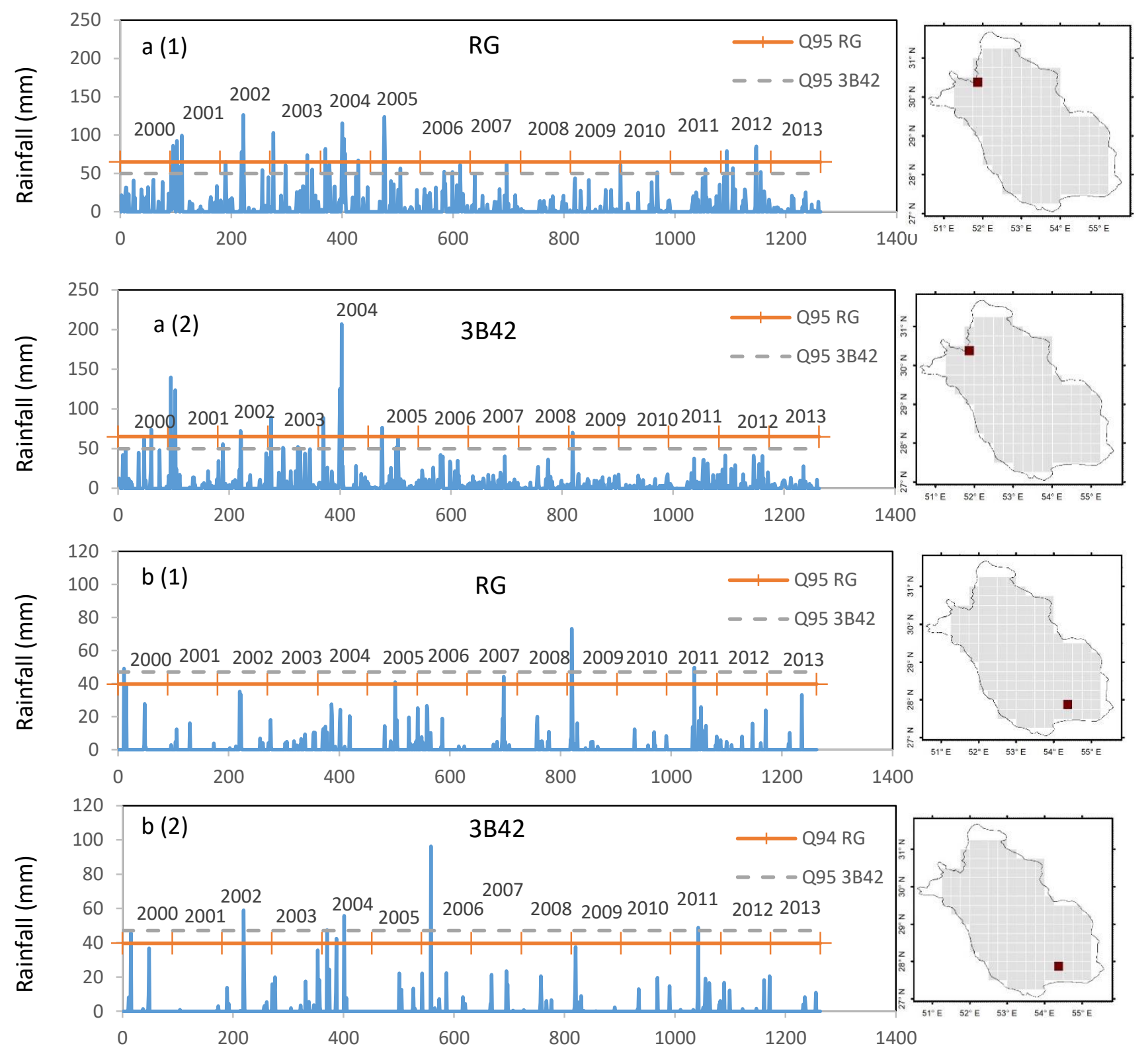

Figure 13. Time series of daily precipitation at two locations (a) $30.375^{\circ} \mathrm{N}, 51.875^{\circ} \mathrm{E}$ and (b) $27.875^{\circ} \mathrm{N}, 54.375^{\circ} \mathrm{E}$ for 14 winter seasons as depicted by (1) RG and (2) $3 \mathrm{~B} 42$. 

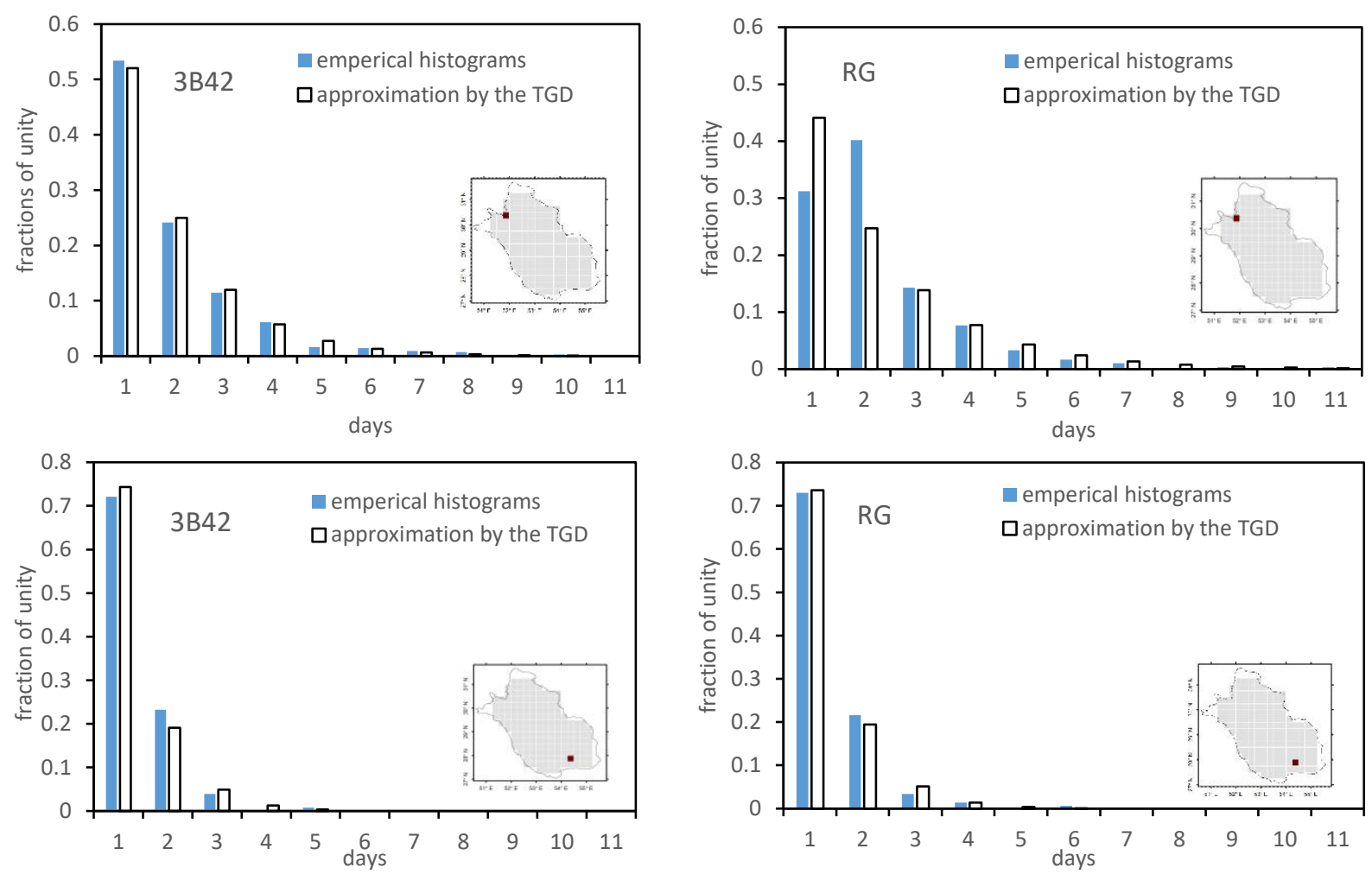

Figure 14. Examples of empirical histograms of WPs durations for the two selected grid cells (dark pixels in the maps) for wet season (October-March) during 2000-2014, as well as their approximation by the TGD. 